\title{
WestVirginiaUniversity
}

THE RESEARCH REPOSITORY @ WVU

Graduate Theses, Dissertations, and Problem Reports

2010

\section{The once and future steel town: The narrative identities of a local community}

Jason R. Rine

West Virginia University

Follow this and additional works at: https://researchrepository.wvu.edu/etd

\section{Recommended Citation}

Rine, Jason R., "The once and future steel town: The narrative identities of a local community" (2010). Graduate Theses, Dissertations, and Problem Reports. 854.

https://researchrepository.wvu.edu/etd/854

This Thesis is protected by copyright and/or related rights. It has been brought to you by the The Research Repository @ WVU with permission from the rights-holder(s). You are free to use this Thesis in any way that is permitted by the copyright and related rights legislation that applies to your use. For other uses you must obtain permission from the rights-holder(s) directly, unless additional rights are indicated by a Creative Commons license in the record and/ or on the work itself. This Thesis has been accepted for inclusion in WVU Graduate Theses, Dissertations, and Problem Reports collection by an authorized administrator of The Research Repository @ WVU. For more information, please contact researchrepository@mail.wvu.edu. 
The Once and Future Steel Town: The Narrative Identities of a Local Community Jason R. Rine

\begin{abstract}
Thesis submitted to the
Eberly College of Arts and Sciences

at West Virginia University

in partial fulfillment of the requirements

for the degree of
\end{abstract}

Master of Arts

In

Applied Social Research

Dr. Lawrence Nichols, Ph.D., Chair

Corey Colyer, Ph.D.

Ronald Althouse, Ph.D

Department of Sociology and Anthropology
Morgantown, West Virginia

Keywords: Weirton; Weirton Steel; Narrative Identity; Deindustrialization; Steel Mill;

Job Loss

Copyright 2010 Jason R. Rine 


\section{Abstract The Once and Future Steel Town: The Narrative Identities of a Local Community Jason R. Rine}

This thesis examines the changing identity of a local community, Weirton, West Virginia, in terms of narratives shared by members of that community. Weirton was home to Weirton Steel, one of the largest steel mills in the United States. Since 1909, when Weirton Steel was founded, the mill provided residents with a narrative. However, this is starting to charge. With Weirton Steel's final closure on the horizon, Weirton will lose the main defining characteristic it has relied on throughout the years. In order for the community to maintain its unity, it must now create a new collective narrative. The research has both a historical and a future orientation. I briefly show how Weirton and Weirton Steel's narratives have been linked since 1909, and how their shared narrative evolved. The research shows that there have been three historical narratives: the model company town narrative, the survival narrative, and the betrayal narrative. It also shows that there are three possible future narratives developing: the ghost town narrative, the bedroom community of Pittsburgh narrative, and the revitalization narrative. 


\section{Contents}

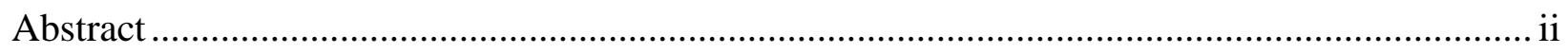

Chapter One: Statement of Problem and Justification .......................................................... 1

Review of Literature: Deindustrialization............................................................................... 4

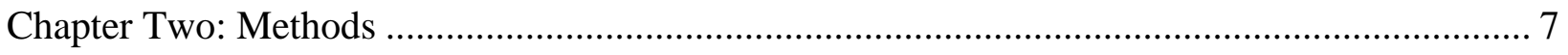

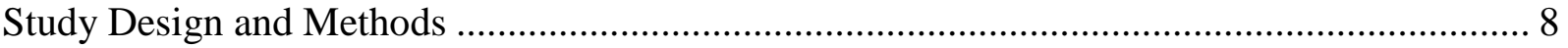

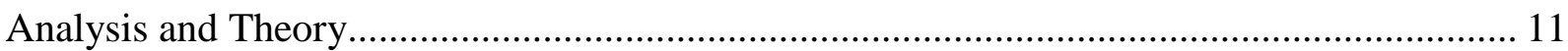

Review of Literature: Community Studies .................................................................... 12

Chapter 3: History of Weirton and Narrative Identities.......................................................... 16

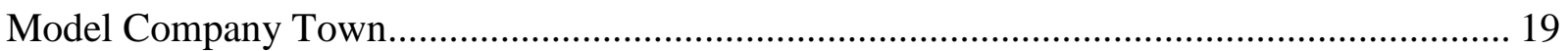

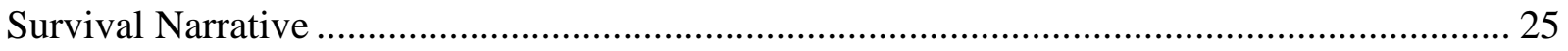

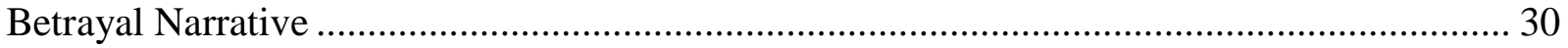

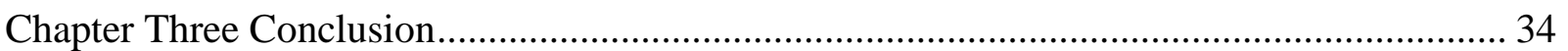

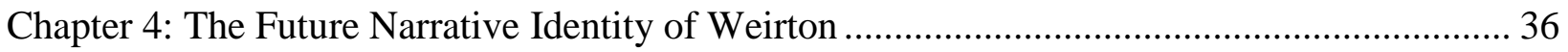

About the "I am From Weirton, WV” Facebook Group ........................................................ 38

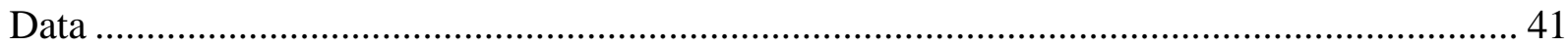

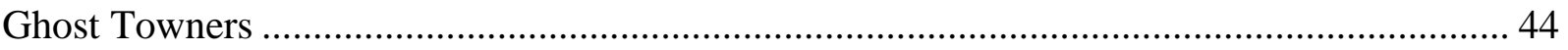

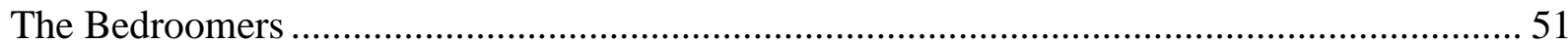

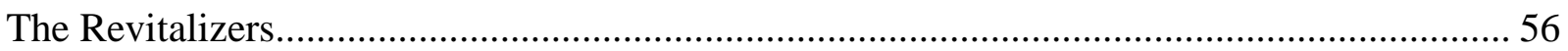

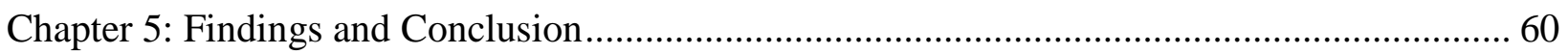

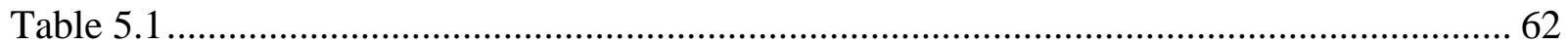

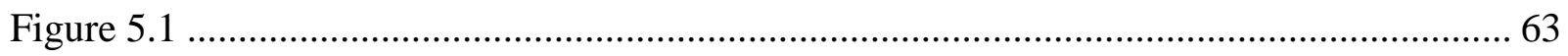

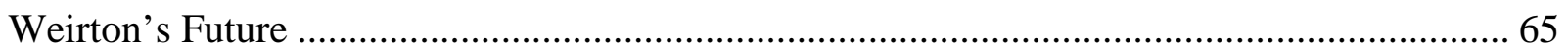

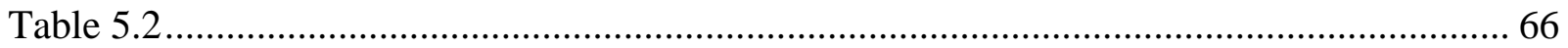

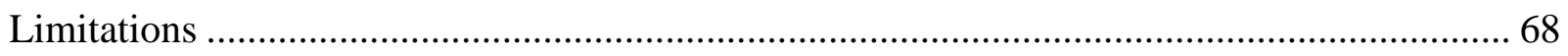

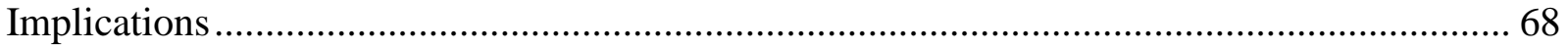

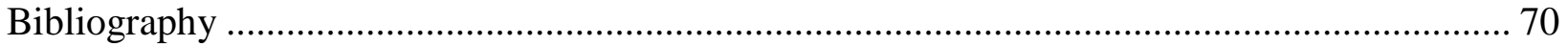

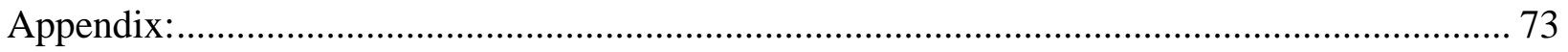




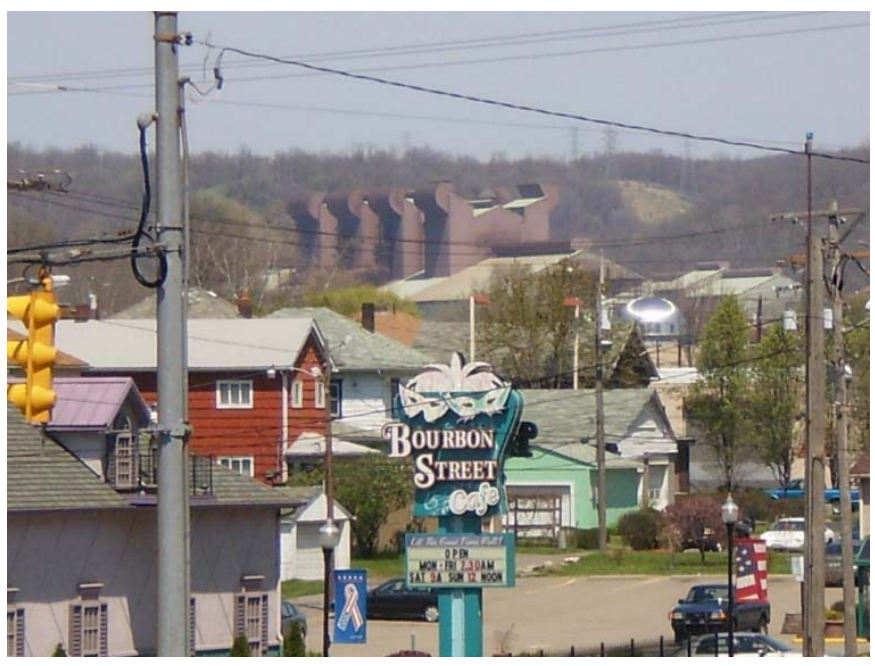

Russell Rine

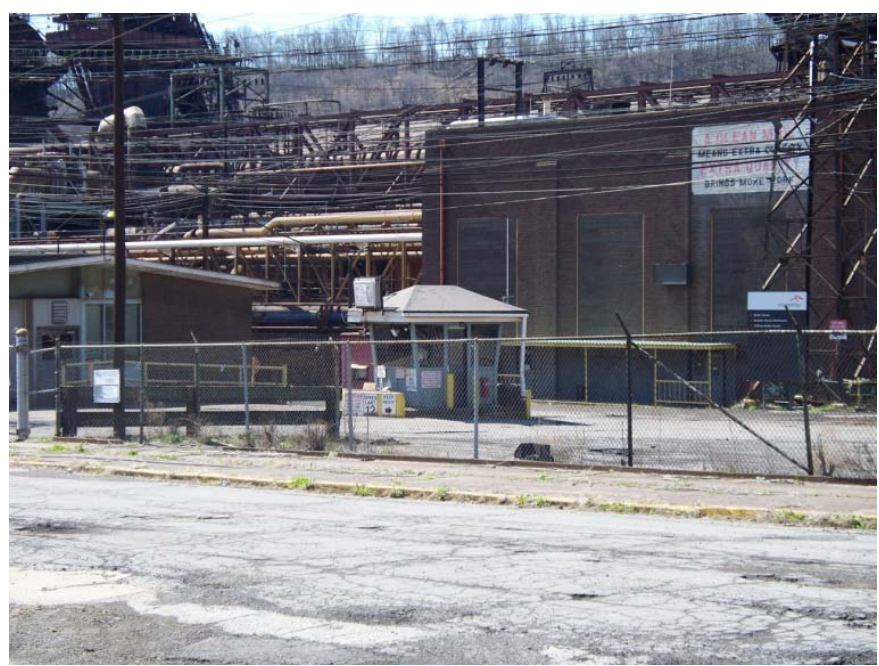

Jason Rine

Chapter One: Statement of Problem and Justification 
This qualitative thesis examines the changing identity of a local community, Weirton, West Virginia, in terms of narratives shared by members of that community. The narratives are the stories and meanings that individuals construct to make sense of what is happening around them. Weirton was home to Weirton Steel, one of the largest steel mills in the United States. Since 1909, when Weirton Steel was founded, the mill provided residents with a narrative. However, this is starting to charge. With Weirton Steel's final closure on the horizon, Weirton will lose the main defining characteristic it has relied on throughout the years. In order for the community to maintain its unity, it must now create a new collective narrative.

The research has both a historical and a future orientation. I briefly show how Weirton and Weirton Steel's narratives have been linked since 1909, and how their shared narrative evolved. The research shows that there have been three historical narratives: the model company town narrative, the survival narrative, and the betrayal narrative. It also shows that there are three possible future narratives developing: the ghost town narrative, the bedroom community of Pittsburgh narrative, and the revitalization narrative. These findings will be very significant for future researchers who are interested in the fates of former factory towns that have been ravished by deindustrialization. I also plan to build on this research in the future by doing comparison studies. I could examine the differences and similarities between a city like Flint, Michigan which has been devastated by deindustrialization, and Weirton. Future researchers could see what helps a city survive the effects of deindustrialization, if Weirton does in fact survive.

By examining the history of Weirton, I show that Weirton has always had a core narrative identity. Since 1909, when Weirton Steel was founded, the city has had a core identity revolving around the steel mill. Weirton was the ideal model company town from 1909 until 1980. The community's core identity from this time period was directly linked with the narrative identity of 
Weirton Steel. In the 1980's the narrative of the community shifted to one of survival, as the steelworkers successfully created one of the largest employee stock ownership programs (Lieber 1994). Weirton still focused their survival narrative around Weirton Steel, and continued to do so in the 1990's when the betrayal narrative emerges. The citizens felt that Weirton steel was betrayed by company leaders and the United States Government.

In Chapter Three, I show past narratives that have emerged throughout Weirton’s history. By performing a qualitative content analysis on historical documents that I have obtained from the community, I am able to show that Weirton had a collective identity and what the elements of that identity were as time moved forward. I have also completed a qualitative analysis of local media and national media that have covered Weirton and its ongoing saga. This also shows that Weirton can be considered a landmark narrative of steel towns facing deindustrialization.

Weirton and Weirton Steel's narrative have been consistently linked since the formation in 1909. However, Weirton Steel is in its final days and the community is struggling to reinvent itself. Now that Weirton Steel will no longer be in the mix, Weirton is going to have to have a narrative that is not linked to Weirton Steel. The main objective of this thesis is to show what happens to a community's narrative after the main symbol defining its identity no longer exists.

One of the leading factors in the decline of Weirton and other major steel towns across America has been the process of globalization and the deindustrialization that it causes. Deindustrialization has been crippling cities in America since the 1980s. There have been many sociological studies on deindustrialization and its consequences for the people who are affected by it and the community. 


\section{Review of Literature: Deindustrialization}

Barry Bluestone and Bennett Harrison (1984) define deindustrialization as a "widespread, systematic disinvestment in a nation’s basic production capacity.” Bluestone and Harrison (1984) also demonstrate that deindustrialization hit certain industries, such as steel, very hard, especially in the "rust belt" because those cities were losing their steel mills at a fast rate. They did this research at a time when there was speculation that deindustrialization was not occurring in the United States, and showed that employment in certain industries, like steel manufacturing, was heavily decreasing. Weirton, however, was able to survive almost 25 years after steel mills across the United States were shutting down for good. Weirton Steel was resilient and did not follow the trend of steel closures in the 1970s and 1980s.

There have been many studies about the effects of plant closures on individuals. Lee Hamilton, Clifford Broman, William Hoffman, and Deborah Renner (1990) conducted research on how a General Motors plant closure affected those who lost their jobs. The researchers used in-depth interviews of former employees who have lost their jobs in Michigan. Their study showed that while plant closings have a negative effect on mental health, they had a worse effect on less educated African Americans and women than on white men. Kenneth Root (1984) conducted research with data from three different plant closures over a period of six years. He compared how people have coped with loss of jobs in three different cases. Using secondary data analysis, he finds that people who lose their jobs tend to rely on family more and are likely to have more stress when finding a new job proves to be extremely difficult. Many people in Weirton have been going through this process as a result of Weirton Steel's situation.

Tim Knapp and John Harms (2002) researched the effects of job loss on workers of a Zenith television plant in Springfield Missouri that closed in 1996 due to illegal foreign imports. 
This study was very unique because Springfield was experiencing growth while the shutdown took place, but the workers were still unemployed for forty weeks before finding new work. Their study found that most of the former Zenith employees had negative attitudes toward management, the United States Congress, and the government. This study closely matches what is going on in Weirton. One of the main factors in Weirton Steel's fall was the illegal foreign imported steel that was being brought into the United States. Weirton is also experiencing some minor growth; however, it is mainly in the form of new shopping centers opening. This was the same type of growth that was taking place in Springfield, and workers probably resisted finding new jobs in the service economy that paid much less than their former manufacturing jobs.

Some of the more interesting research on plant closures and deindustrialization has focused on their effect on the community. George Lord and Albert Price (1992) talk specifically about the "growth machine" model or growth ideology, which is a strategy used by communities trying to offset the heavy blow delivered by deindustrialization. An example of promoting growth would be to try to stimulate tourism within the community. The communities continue to use money to spur growth, however, this can lead to even more decline and usually does not benefit the citizens. It seems as though Weirton is trying to use the growth ideology to spur the tourism industry with gambling establishments to attract people to the community. A new Super Wal-Mart is being built and new development is being built in the surrounding areas. Ironically, the new Super Wal-Mart and shopping centers are on the location of the old Weirton Steel Headquarters in Weirton.

John Logan and Harvey Molotch (1987) also talk about growth ideology, stating that growth does not create jobs but only moves them around the country. Analytical, quantitative research on the state of New York has taken data from 1962 through 1976 and has shown that 
when deindustrialization comes to town and manufacturing jobs are lost, social services are strained and property taxes decline (Wu 1987). The newly unemployed are going to be looking for social services; however, the money will not be there to fund the social services. The same can be seen in Weirton, because as the city loses its main source of tax revenue, Weirton Steel, then unemployed steel workers will start overloading the social services system, just as $\mathrm{Wu}$ as shown in his study.

The process of deindustrialization has been leaving cities in America bankrupt and families looking for new ways to survive (Bluestone 1982). Globalization is a huge social problem in America and Weirton is just one of the many cities facing this massive social problem. However, Weirton is a unique case because of the way the community came together to fight deindustrialization. In 1982, the employees of Weirton Steel opted to take a pay cut in order to pay for the purchase of the steel mill from National Steel to keep it in operation (Lieber, 1995). Even in the wake of this big success story, the forces of globalization were still at work and it seemed as if this huge move by the community to buy the steel mill only bought more time. As the ability to communicate over the world quickly became a possibility, globalization and deindustrialization started to accelerate, leading to the inevitable closure of Weirton Steel (Best 2008). 


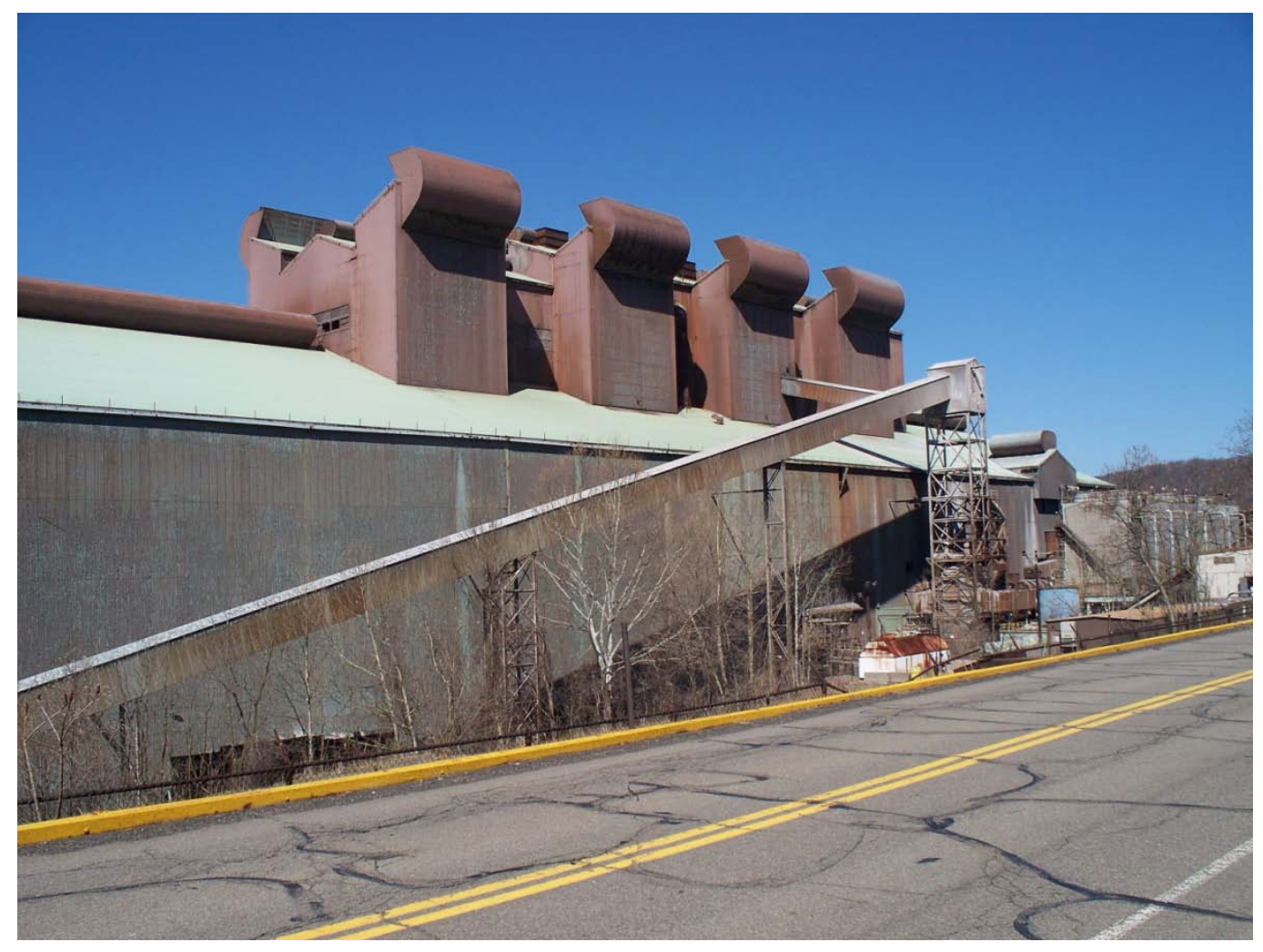

Jason Rine

Chapter Two: Methods 


\section{Study Design and Methods}

This research gathers data in several ways, including a qualitative content analysis of historical data and a survey sent out to members of the group, "I am from Weirton, WV"1 Facebook social networking website. In order to collect earlier narratives, I preformed a qualitative content analysis of documentary and archival data. To gain access to historical documents of Weirton, I became an active member of the Weirton Area Museum and Cultural Center. I also sent the questionnaire to members of the Weirton City Council and union leaders, asking them where they believe Weirton's future lies. This will show whether the expectations of community leaders are closely aligned with those of current and former citizens.

The Facebook group, “I am from Weirton, WV”, has 1,549 members. I believe that one of the best ways to contact current and former residents of Weirton is through the Facebook group, because of the large membership size, the significant active postings in the group, and a large range of ages. I observed online interactions among Weirton Facebook group members and deployed a survey to the members of the Facebook group to reveal the emerging narratives of Weirton. As of 2005, the population was 19,224.

The members of the group post discussion topics to which other members reply. Some of these topics are: “Things that are not in Weirton any more (and you wish they/it were)," “If you could bring the city back to life what would you do?," "Why are you proud to be from Weirton?,” and “Should Weirton reinvent itself somehow?” A content analysis of these discussions will provide rich data and should help reveal past narratives and possibly some of the

\footnotetext{
${ }^{1}$ http://www.facebook.com/home.php\#/group.php?gid=47222585697\&ref=ts
} 
emerging narratives. I also analyzed the comments people make on the wall of the group, which is the group’s bulletin board.

My original plan was to post my research answers in the discussion section of the group and let other member find the discussion themselves. The discussion was posted exactly as the questionnaire in the index. I posted on the group’s bulletin board or wall every few days in order to spur more responses. In one month, only ten people had responded to my survey. The discussions also got off track, because group members would not read my initial post with the questionnaire, but instead, would read the response of the last person who posted in the discussion and add on to that post. This was not the way to proceed as I was getting answers on memories of Weirton and people did not discuss the direction they believed Weirton was heading.

I reflected on the way that I use Facebook, and I realized that I rarely keep up with the groups that I join. I discovered that only the group creator and the administrators would be able to send out mass messages to all members. Therefore, I contacted the group creator and told him about my research and what I had hoped to accomplish. He sent me a message back within a day and told me he would be happy to help and even sent out a message to all of the members introducing me to them.

The mass message that was sent to the entire Weirton group included a questionnaire that can be found in the appendix. The 1,459 members of the group are my sampling frame. The first question on the questionnaire is, "What will be the next chapter in Weirton's story? For instance, do you believe that Weirton will develop a new industry, become a ghost town, or become a bedroom community of Pittsburgh? Do you have a more optimistic or pessimistic view of 
Weirton's future?” This question will be the heart of the questionnaire. It exposes exactly what the individual believes awaits in Weirton's future and if they are pessimistic or optimistic about it. It seems that the likely scenarios for Weirton are either becoming a bedroom community of Pittsburgh or a ghost town, or else developing a new industry and maintaining its independence and becoming productive again. The three pre-chosen answer choices, that Weirton will develop a new industry, become a ghost town, or become a bedroom community of Pittsburgh, were given as options because in preliminary research, those three answers were consistently given as answers.

The second question is designed to expose why respondents came to Weirton, why they left and when. The following question, "Were you or a member of your family ever employed at Weirton Steel?” will expose the individual's relationship to the steel mill and will be important in analyzing the data to determine whether there is a difference in opinions between steelworkers and non-steel workers. The next question, "What about Weirton is most memorable to you and why?" can help expose some of the past narratives. Next I will ask, "I would also be interested in any comments regarding: Political leadership, community leadership, how Weirton was treated by national leaders, or anything else you think would be helpful to my study.” This question will expose people's feelings toward political leaders, community leaders, and national leaders. It also gives them the opportunity to share anything else they would like. Finally, I ask them if they are male or female and their age. This will make it possible to compare gender and age groups to see if there is a difference on the opinion of Weirton's future.

I realize that there has been some disagreement about who has the right to study a community; Denzin, for example, believes that outsiders should not intrude into a community in order to study it, while Whyte replied that he had done a service to the community (Denzin 1992, 
Whyte 1993). While most of the people who studied communities were considered outsiders, I am considered an insider because I am from Weirton. However, because of my role as a researcher, there is an element of being an outsider that will be seen by the citizens of Weirton (Bell and Newby 1974). Participant observers who conduct community studies are mostly considered more as outsiders but have a slight element of being insiders because of their participation. However, I will have the opposite situation. I will be mostly considered an insider but will also have a slight outsider connotation due to the fact that I am a researcher. This thesis can also be considered "participatory research" in the sense that I treat respondents as partners and am making my final results available to them. The community of Weirton, including both current and former citizens, may therefore benefit from my research.

\section{Analysis and Theory}

I am using the grounded theory approach (Corbin and Strauss 2007) while analyzing the historical documents from Weirton and the data from the questionnaires and the discussions observed in the Weirton Facebook group. The questionnaire can be found in the appendix. In this thesis I assume that there is a need for a new narrative that is appropriate for Weirton's citizens to use as a sense making paractice. A new shared narrative may meet group needs to adapt to new environments and to maintain a sense of unity. Using axial coding, I have looked for indicators of each category that I believe are emerging. When I saw similar elements across different e-mails I knew that there must be a linkage. I have taken time to verify the linkages to make sure that they are, in fact, there. It will be important to make sure that the empirical world or reality is connected with the categories that I am coming up with.

I have theoretically sampled the members of Facebook who are members of the "I am from Weirton” group. I analyzed the e-mails as they came in, to make sure that I have 
documented all of the categories that are possible. I wanted to make sure that my research was completely saturated with the data to expose all the possible emerging narratives of Weirton. Nothing new should be able to emerge by the time I am done analyzing the data the e-mails will deliver.

\section{Review of Literature: Community Studies}

As Colin Bell and Howard Newby (1974) show in their review of the literature, many community studies in sociology have focused on social class, race, and social change within a community. Bell and Newby’s definition of community includes territorial area, complex institutions, and a sense of belonging. Weirton encompasses all of these elements. Weirton obviously has a territorial area, but is also has a very complex institution in Weirton Steel. Through viewing the history of Weirton, one can see that there is a strong sense of belonging. If what finally bonds a community together is its state of mind, then the gathering of opinions from the people connected to the community will surely paint an impressive picture of the past narratives of the community. Some criticize community studies because of their lack of quantitative data and claim that they read like novels. However, Bell and Newby point out that comparing community studies to a novel is a good thing, because community studies, like novels, provide vivid accounts of what is happening in the community.

According to Bell and Newby community studies should use a community’s history in order to give the community some dimension. I am using the history of Weirton to expose the past narrative identities that can be found in the community. They also disclose that the best community research comes from those who took the time to become insiders in the community that they were studying. I will have an advantage in my research because I am an insider, and I have close connections to my informants. 
One of the first major community studies was conducted by Robert and Helen Lynd, who were able to examine Middletown both before and after the city went through the process of industrialization. They found that family became less and less a component of leisure activities and friends started to play a more intricate role as industrialization set in. The Lynds also discovered that, after industrialization, there was one family that had resounding political influence in the city because they were the owners of the glass factory that opened there (Bell 1974). The research on Weirton expands on the Lynd's study since they were able to examine a community before and after it went through the process of industrialization. I will, on the other hand, be researching Weirton during industrialization and into the community's process of deindustrialization. This will expand upon the Lynds' work by adding a new dimension to the research.

Another classic community study focusing on class is William F. Whyte's, Street Corner Society. Whyte (1942) had to gain the trust of the members of the community and actually live there for an extended period so that he could gain access to the community. He examined the slum of Cornersville in order to determine how the people organized in groups and what the relationship was between the politicians and the local corner boys. Whyte had to work to gain access to the community; however, I already am considered an insider to the community because I am a lifelong citizen of Weirton. I am viewed by the community as an insider and will not have to go to the great lengths that Whyte did to in order to gain the trust of the community.

W. Lloyd Warner's “Yankee City” series also made social class its central focus. Warner believed that social space had two dimensions: the vertical dimension was an individual's place on a social hierarchy, while the horizontal was their social deviation at their vertical level. 
Warner discovered that everyone in the community fit into one of six classes, ranging from upper upper to lower lower.

Other community studies have been based mainly on race. In a classic study of caste and class in a smaller town, John Dollard discovered that white men are allowed sexual relations with black women, but black men cannot have sexual relations with white women. He conducted indepth interviews with African Americans and mainly used participant observations for the whites. Carol Stack (1975) discovered that in a poor African American community reciprocity and kinship are the keys to survival. It seems as though the steelworkers in Weirton will probably rely on kinships that they developed in the city as more of them become unemployed.

The Chicago School produced many community studies which focused on social disorganization. Frederick Zorbaugh found that a rich community's citizens had no idea of what was happening in the slums right behind them (Bell 1974). He argued that the slums had no sense of community because there was a turnover rate of every four months; therefore, he concluded that community was only geographical. Robert Park believed that every city has a local organization of "natural areas," including the central business district, middle class neighborhoods, and the slums. He also developed the idea of succession, which states that as a city grows certain segments are invaded and taken over by citizens of different ethnicity or class. Weirton has many areas that are natural areas that are geographically split up. For example there are downtown shopping plazas, and another part of the city with a shopping center that is usually referred to as "up on the hill”.

Maurice Stein (1960) examines change in communities based on an in-depth analysis of American community studies. He argues that urbanization, industrialization, and bureaucracy are 
the main components of social change. Urbanization is loosely defined by Stein as a social force that draws people toward the city. Stein uses Zorbaugh's The Gold Coast and the Slum to study how natural areas can develop right next to each other, but have no social network to one another whatsoever. He shows that the urbanization draws people into cities and creates natural areas that can be isolated from one another. He cites the Lynds’ Middletown study to show how industrialization has changed the community dynamics and Warner's Yankee City to show the effects of bureaucracy when a shoe manufacturer is sold to a national company.

This thesis based on Weirton will expand on Stein's work, because he believes that urbanization, industrialization, and bureaucracy are the main components of social change. If these factors spur social change, one could argue that another main factor in social change is deindustrialization. This has been a force that has caused people to lose their jobs and abandon cities across the United States in search of new places to live and work (Bluestone 1984). Therefore deindustrialization seems as though it fits into the category of a social force that would create social change.

Community studies have been broad and have used many different methods in order to discover the social dynamics within a community. Using a historical analysis, as suggested by Bell and Newby, along with the survey results from the Facebook group, makes this research stand apart from any other community studies that have been conducted. As I take on the role of a researcher, I am also considered and insider by those who are responding to the questionnaire. This research will also add a new methodology technique for the collection of data in community studies. 


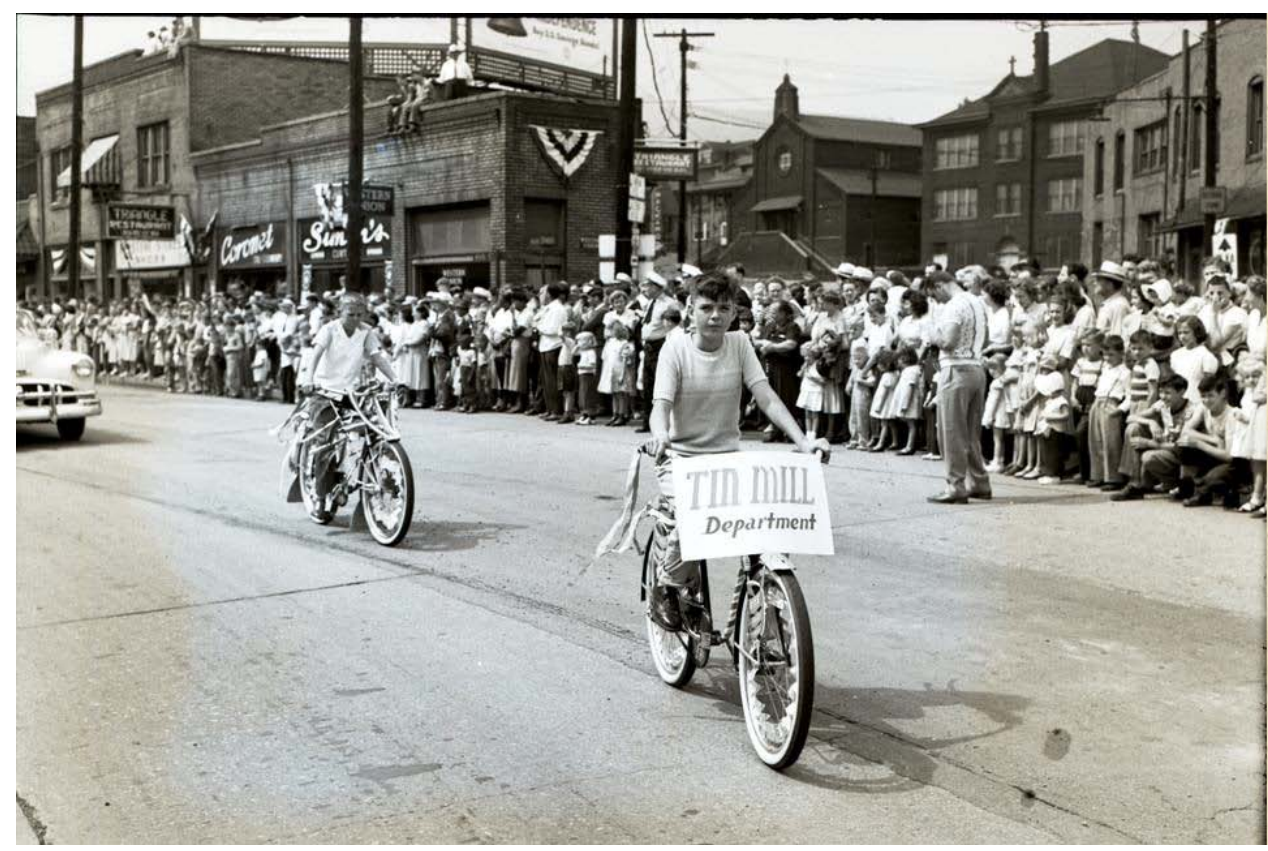

\section{Preserving Our History and Culture}

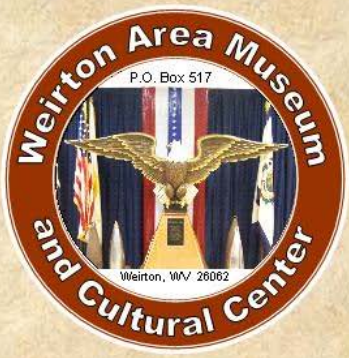

for Future Generations

Permission from Weirton Area Museum and Cultural Center

Chapter 3: History of Weirton and Narrative Identities

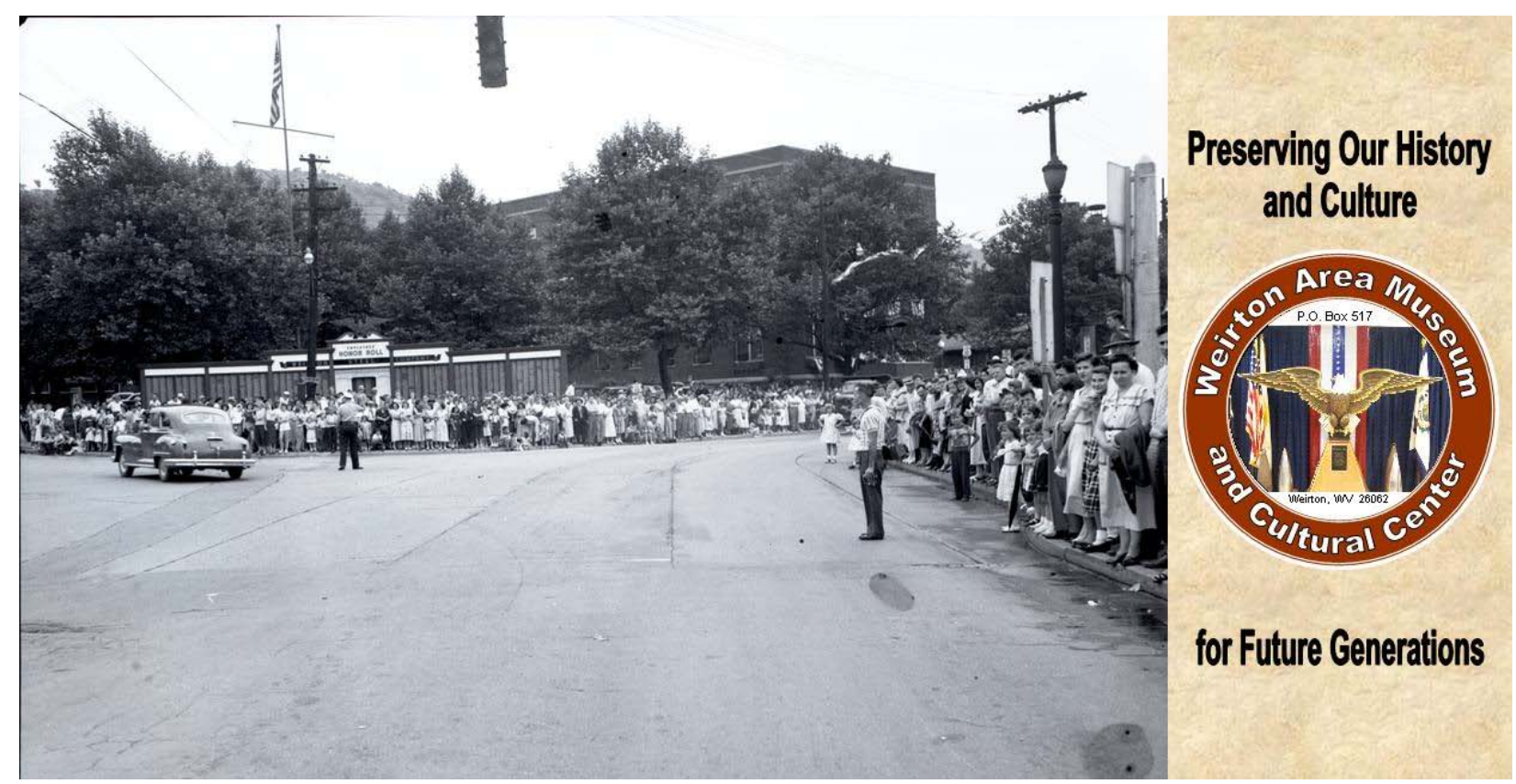

Permission from Weirton Area Museum and Cultural Center 
The main purpose of this chapter is to show how Weirton's narrative identity has changed over time by conducting a qualitative content analysis of local and national media and Facebook. I will also use this project to show that a community, such as Weirton, has a collective narrative identity, much like that of individuals. By using the grounded theory approach and allowing the data to come up the categories, three narrative identities emerge when viewing the history of the Weirton: the model company town narrative, the survival narrative, and the betrayal narrative. I have examined the histories of Weirton and Weirton Steel to show how the narratives of the two are interlinked. I have also used Facebook to contact members of the group, "I am from Weirton, West Virginia”, to gather their memories of the community.

I have tapped multiple sources for uncovering the past narratives of Weirton and Weirton Steel. By becoming a member of the Weirton Area Museum and Cultural Center, I have identified multiple local media sources: Weirton Steel Bulletins, Weirton Daily Times articles, documentaries on the steel mill and the community, and The Weirton Area History Game. I have also been analyzing Facebook survey responses and have included quotes throughout the research. Analyzing these materials will show that Weirton has had a collective narrative identity and that this identity has changed over time as the older narratives no longer applied.

Weirton's narrative identities have evolved over the years as the situations in Weirton have changed. When the city was first founded, it was named Holliday's Cove, and was a rural agricultural community. Holliday's Cove was prosperous because of its location right along the Ohio River. One could argue that the narrative identity of a farming community emerges in this time period. The Weirton Area Museum and Cultural Center has many documents describing in detail what Holliday's Cove was like before the arrival of Weirton Steel. Pictures of the Valley show the land before the steel producing giant outlined the landscape. 
In 1771, the first settler, Harmon Greathouse, came to the area. The village, Holliday’s Cove was founded in 1773 and was named after John Holliday, who set up the first trading post. In 1861, the population was 250 people, who had to set up forts for protection from Native Americans. The farmers grew corn, wheat, and apples (Jones 2009 B). This is the first settlement in the area, and you could argue that the narrative identity before the Weirton Steel was that of a small farming community village.

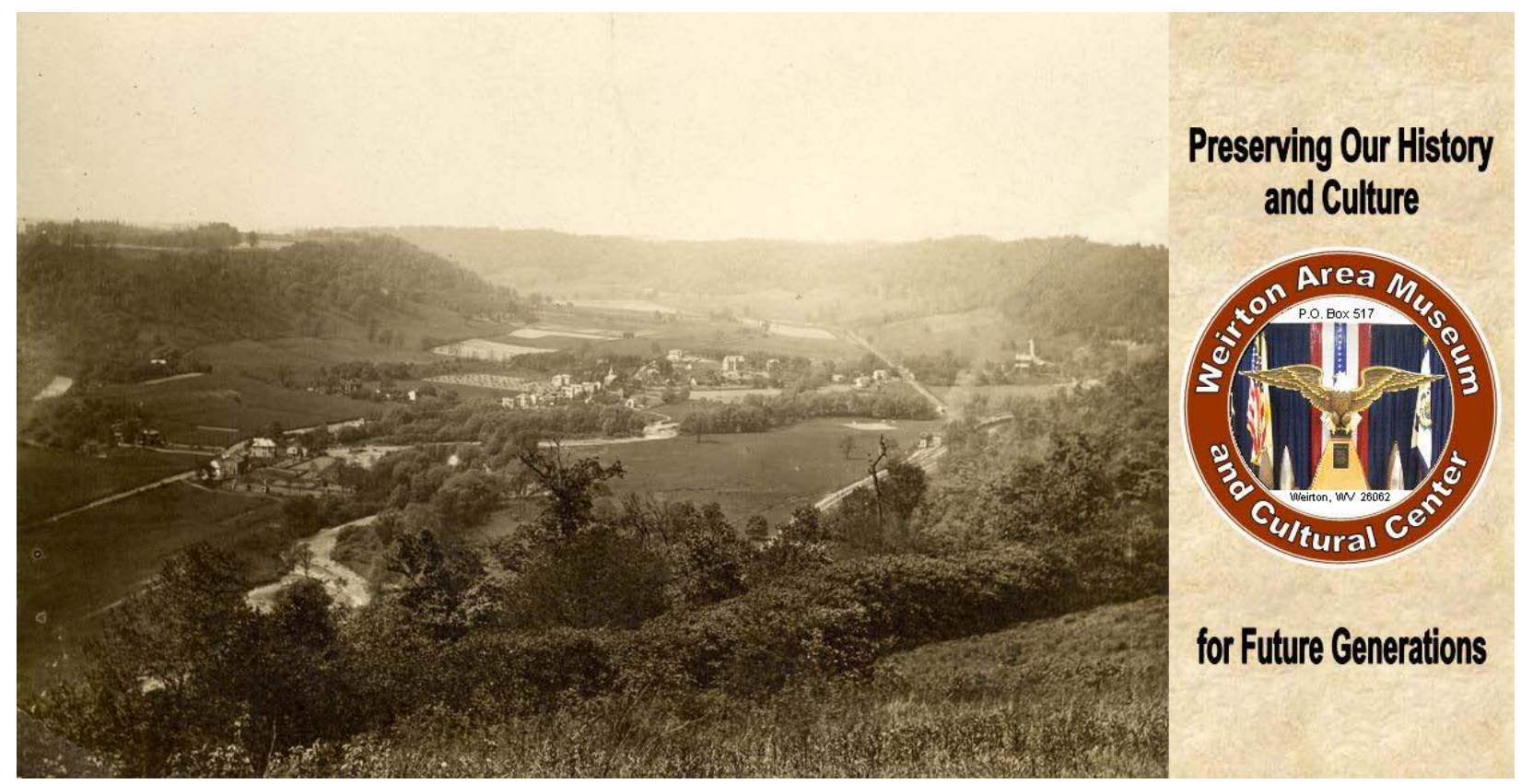

Permission from Weirton Area Museum and Cultural Center 


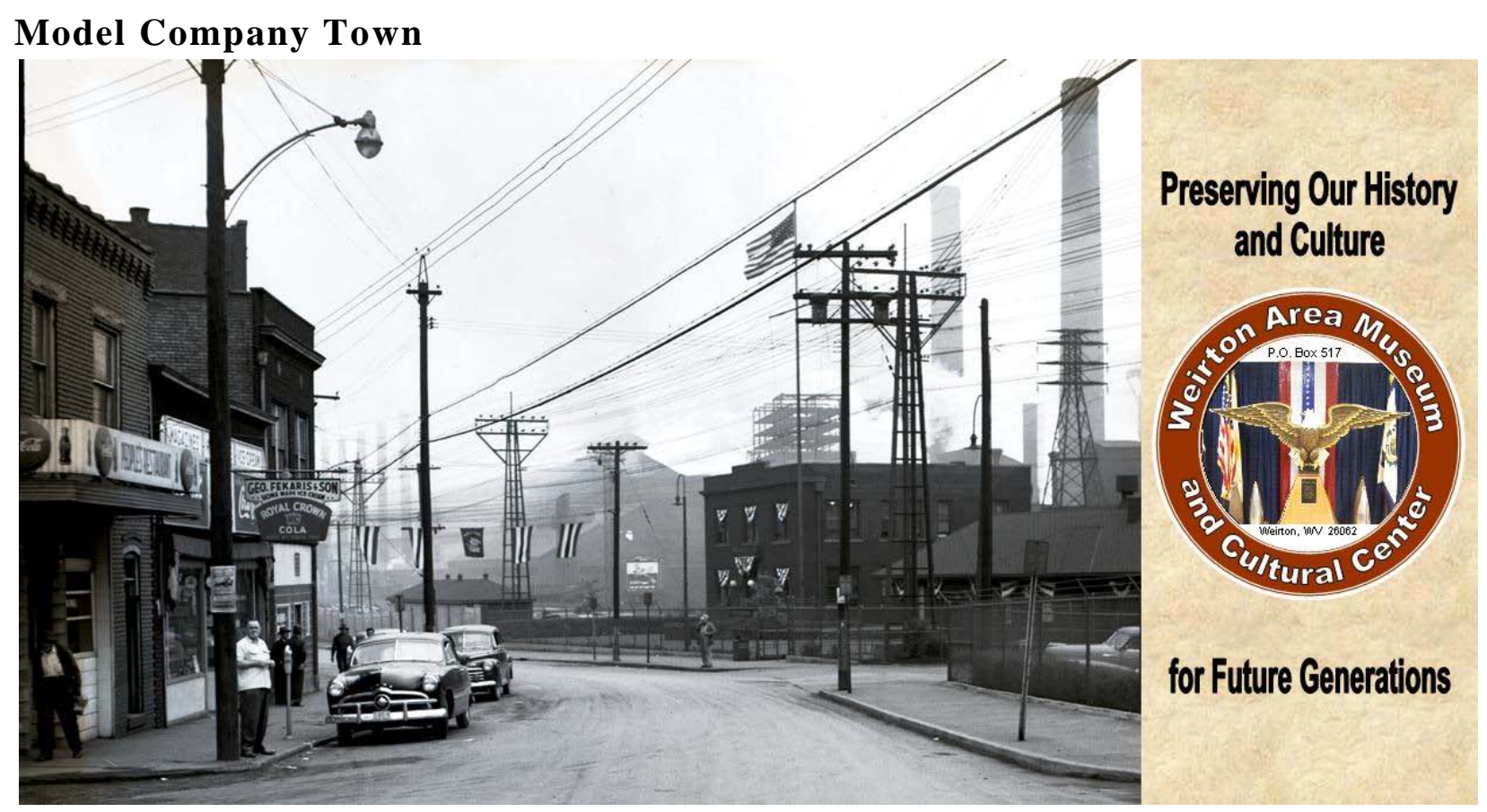

Permission from Weirton Area Museum and Cultural Center

Ernest T. Weir, President of Philips Sheet and Tin Plate Company, bought 105 acres of apple orchards in the Northern Part of Holliday’s Cove. The steel mill opened in 1909 and in 1918, Philips Sheet and Tin Plate Company officially changed its name to Weirton Steel (Jones 2009 B). As the Steel mill grew, so did the city around it. Weirton was considered the largest unincorporated city in the United States until it incorporated Holliday’s Cove, Marland Heights, and Weirton Heights, to officially become the city of Weirton in 1951. The President of Weirton Steel at the time was Thomas C. Millsop and he was elected as the first mayor of Weirton.

With the success of Weirton Steel, E.T. Weir bought and merged mills in other parts of America. He created and became the C.E.O. of National Steel. In 1929, National Steel was created when Weirton Steel merged with The Great Lakes Steel Corporation and the M. A. Hanna Company. Weirton Steel became a division of National Steel, which would eventually grow to be one of the largest steel producers in the United States (Jones 2009 B). 
During the time period from 1909 until the 1980s Weirton has the narrative identity of the ideal company town. Many people have negative connotations of company towns when viewing coal towns in southern West Virginia; however, Weirton embodied a completely different company town atmosphere. While others in the steel industry and manufacturing sector eagerly accepted becoming part of a national union such as the Congress of Industrial Organizations (CIO), the community of Weirton resisted. Weirton Steel had its own union, and did not wish to become members of a national union. The employees in Weirton were happy with the leadership of the steel mill and did not feel as if they needed an outside source to communicate with management (Lieber 1994).

Weirton's union timeline is very interesting and shows its determination to keep national unions out of town. In 1933, Weirton Steel employees rejected becoming a part of the Amalgamated Association of Iron, Steel and Tin Workers. Instead, they created the Employees Representation Plan, whose leaders were on the company payroll (Lieber 1994). In 1941, Weirton Steel's union became the Weirton Independent Union. In 1951, a federal court it was declared that the Weirton Independent Union was created and controlled by management and that it would therefore have to be replaced (Jones 2009 B). Representation of the CIO was outvoted 7291 to 3454, and the new union representing Weirton Steel workers would be the Independent Steel Workers Union. This union still had leaders on Weirton Steel's payroll and remained independent from national unions until 2007. This further shows the citizen's commitment to Weirton Steel during this period because they were unwilling to give in to an outside union.

This era (1909-1980) in Weirton was the golden age for the community and Weirton Steel, whose narratives were completely linked. At its peak the steel mill had approximately 
14,689 workers. The community was untouched by the Great Depression in the 1930's and Weirton Steel's wages supported well over two hundred and fifty local business (Lieber 1994). The community drew workers from surrounding areas because word got around that Weirton Steel was still doing well. Weirton Steel often worked together with Weirton in various ventures across the community. When Weirton Steel was in its prime, the company would clear the roads in the winter, put up Christmas decorations across the city, and heat the Millsop Community Center free of charge. A Facebook respondent reaffirms what I have discovered at the Weirton Area Museum and Cultural Center:

The mill put a lot of money into the community. The city never had to raise much money as they do now. They just asked WSX (Weirton Steel Corporation) for the money for parades, festivals, Marland Heights pool, and the Community Center. (59, Female).

During World War I and II, the women in the community came together to work in Weirton Steel while their husbands were away at war. In 1944, the workers of Weirton Steel received the E awards from the American Army for continued production throughout the war. By the end of World War II, Weirton had two Silver Star renewals on The E award flags that flew over the steel mill. The E award acknowledged excellence in war production (Jones 2009 B).

The community also has prided itself in diversity. From 1932 until 1939 Weirton held annual festivals called the Festival of Nations. They were meant to celebrate the ethnicities of the city. Weirton Steel is credited as one of the main sources for Weirton's range of ethnic diversity. It attracted immigrants from around the world, because Weirton was known to be one of the places were they could find a job. The first Festivals of Nations featured performances by many nationalities that lived in the community, including, Russian, Czech-Slovak, Hungarian, Finnish, 
Italian, Welsh, Greek, Romanian, Jugo-Slavs, Polish, and American. Each of the Festivals had themes and special performances at the end of each year, such as: "Steel is King," "Around the World,” Liberty, Justice, and Peace,” “Homeland Traditions,” and “God Bless America.” In 1940, after the beginning of World War II, the festivals took on more of an American theme which included the U.S. Army coming to town (Jones 2009 A). The annual festivals ended in 1945, because they did not want to strain the army anymore during the war.

Many of the Facebook responses refer to the ethnic diversity and ethnic food festivals when asked what they thought was most memorable about Weirton.

For me, it's the close-knit, ethnic flavor that Weirton has. Despite it being a small town, it has many ties to different cultures that are still celebrated today. (33, female)

This response shows that this respondent believes that Weirton's diversity is still present. Ever since the Festival of Nations, Weirton has always had a strong since of ethnic diversity.

The values of the people here are unbelievable. I think it's because of the different ethnic people that make up the community: Greek, Italian, Polish, etc. People here pride themselves on education, work ethics, family, church, and friends. (Female, 59)

This is another response that refers to the ethnic diversity of the community. The responder also refers to the pride and work ethic that individuals have in the community. These are all elements of the model company town narrative.

While analyzing some of the Facebook material, I was able to pull some quotes about Weirton describing its success from the model company town narrative time period. 
Back when I was a kid in the 60's Weirton, WV was an all American town. We had it so good! The plaza up on the hill was a great place to shop and there was the bowling alley on Weirton Heights and it had a great bar where we hung out and grooved on the disco tunes in the 70s...There was so much to do back then, everything was kept up and there were plenty of jobs for everyone. I have great memories of Weirton, wish we could all go back in time and visit. Poor Weirton is a shadow of its once-great self but I still love to come home now and then and get some DiCarlo's pizza, greatest pizza in the world. (Facbook)

This quote exemplifies that Weirton was the ideal company town. The person calls Weirton the All American town, which shows the point that Weirton's identity was that of a great place to live. It was the model company town; there were things to do in the city. However, he also says that Weirton is "just a shadow of its once great self,” which shows that Weirton's narrative has changed.

Even though pollution was bad in the community, workers and the citizens defended Weirton Steel,

I remember in the early 70's, when I became aware of pollution and such, we would drive through the North End and it was so dirty - headlights on at times during the day even. I complained once at the dinner table about the mill and the filth and my dad replied, "That's what putting food on the table - forget it" (Female, 51)

Members of the community did not mind the pollution Weirton Steel produced. No Star Nights, a children's book written about Weirton, addresses the pollution that Weirton endured in the 1950s. However, the smoke was seen as putting food on the tables of families; therefore, there was very little community unrest about the pollution. This lends support to the model company town narrative, as we see citizens of the community defending Weirton Steel.

Weirton Steel even had its own publication for the workers of the steel mill. The Weirton Steel Employee Bulletin looks like a magazine and was published from the 1930s until the 1980s. 
It was a once a month publication, until the 80's when Weirton Steel became an employee stock ownership program (ESOP). By examing the Weirton Steel Bulletins before the company became employee owned, one can see the linkage between the community and the steel mill. Not only do the bulletins cover what was happening in the steel mill, they also provide information on what was happening within the community.

Each bulletin features a story about the community and its citizens. For Instance, the May/June issue of 1976 features a bicentennial look at Weirton. The opening article is entitled, "Weirton and its Heritage of Steel." The entire bulletin is outlined with pictures from Weirton and its history with Weirton Steel and the steel industry.

Many of these bulletins feature ways in which community members could help the community of Weirton such as: donating blood, donating time, or donating money to the local chapter of the United Way. The Bulletins also feature family albums in which many different families of steel workers are pictured. They also give detailed information about the local high school sports teams and information on local athletes who are trying to excel in their sport. There are also poems, illustrations, and quotes directed to show the importance of safety in the steel mill. The Bulletin also featured an annual Christmas issue. These issues were lined with Christmas pictures of Weirton family celebrating the holidays. They had a strong Christian element in them, as did most of the other issues which included a Bible verse in the back of each cover.

The Weirton Steel Bulletin exemplifies how connected Weirton Steel was with the community. One would struggle to find other employers who created a publication for their employees directed to the specific community in which they live in. The Bulletins illustrate the 
model company town narrative in every issue. They helped connect the citizens of Weirton with Weirton Steel. The articles and pictures show how much individual lives were influenced by the steel mill.

From 1909 through 1982, Weirton had the narrative identity of the model company town. The community depended on Weirton Steel, and Weirton Steel made substantial efforts to help the community. The workers rejected outside unions and did not contest the pollution the steel mill was creating. Weirton's story, its identity, was integrated with Weirton Steel. The narrative of Weirton and its citizens revolved around the story of Weirton Steel. In the 1980s, however, with the threat of an immediate closure, Weirton's story would have to change.

Survival Narrative -- "In 1982, Weirton, West Virginia was about to become another rust belt casualty, its steel plant slated to be shut down by Nation Steel. Today, Thanks to an innovative employee buyout technique known as ESOP, Weirton Steel is independent, modernized, and ready to enter the twenty-first century.” (Lieber 1994)

In the late 1970s and early 1980s, steel mills across America started shutting down due to the introduction of foreign imports (Bluestone 1982). As America's steel industry started to suffer, National Steel started closing down plants and laying off workers. It was only a matter of time before the Weirton Steel Division would lose all National Steel funding and be shutdown.

In the 1980s, Weirton and Weirton Steel's long run of success would come to a screeching halt. National Steel made a huge announcement that would change the lives and livelihoods of Weirton Steel workers and the Weirton community. National Steel would no longer invest any capital in the operations or upkeep of their Weirton Steel Division. Everyone in the community thought that it was the end of an era. However, there was a glimmer of hope when National Steel announced that it would allow Weirton Steel employees to buy the plant 
from them. If the steel workers of Weirton decided to buy the plant, they would create the largest Employee Stock Ownership Program (ESOP) at that time (Lieber 1994).

The opportunity to buy Weirton Steel, however, depended on the vote from the union workers. If they voted in favor of the ESOP, they would have to take a twenty percent cut in wages and benefits and would not be able to get pay raises for six years. If they voted against it, their jobs would be lost. When the results came in, an overwhelming majority favored the ESOP. They bought the mill for 386 million dollars (Lieber 1994).

For months leading up to the vote the community held huge parades to show support for the ESOP and held fund raisers in order to collect money to help pay for the employee takeover. There was an attitude of pulling together in the town. Murals were painted on the steel mill with the slogan, "We can do it" under them. Telethons and other ways of collecting donations were organized by the Weirton Steel ESOP Fund. Paintings and murals lined the steel mill and the streets, encouraging citizens to stand together to save their steel mill (Lieber 1994). The narrative of a community fighting to survive can be seen through various mediums within the community. One of the Facebook respondents even mentions that the fight for survival is the most memorable thing about Weirton.

When I was under ten, Weirton Steel was still thriving. I witnessed ESOP and saw how the community was driven to maintain its proverbial "bread and butter." (38 female)

The Weirton Steel Bulletins likewise began to transform and took on the, "We can do it" attitude. One of the Bulletins has two pages dedicated to a message about the ESOP, as well as a picture of steel workers with the following text. 
You bet we support the ESOP. A good job is part of the American dream, but so is capital ownership. Weirton Steel employees have the opportunity for both. The Employee Stock Ownership Plan means each of us can own a piece of the action. We'll share in both the risks and rewards, but essentially, we're betting on ourselves. On our know-how, experience and pride in doing superior work, Weirton Steel's tradition of excellence can be the foundation on which to build a promising future. We work here. Now we have a chance to own here. Isn't that what the system is all about? Support the ESOP. Ownership can be very rewarding! (Volume 50 - Number 1)

This excerpt takes up two pages of the bulletin and almost seems like an advertisement for the ESOP. This message includes the phrase, “the American dream.” It shows how Weirton Steel is part of that American dream because it provides the community with good jobs. The phrase, "we are betting on ourselves” also stands out. It gives one the image of the steel workers coming together and sacrificing some of their wages; however, they believe that the community's pride in producing superior work will lead to the success of the ESOP.

The Bulletin also has a picture with a pop can and a beer can that says.

WE CAN DO IT! When it comes to making steel for beverage cans, nobody does it better. And we intend to keep right on doing it with an ESOP. You can count on us. Weirton Steel, an equal opportunity employer. (Volume 50 - Number One) This also displays how Weirton Steel and the community viewed this period as a time when the community would have to come together to survive. The "We can do it" slogan shows a sense of collectivity among the community. The Bulletins also feature local businesses that are contributing to the community's Weirton Steel ESOP Fund.

It was at this point in time that Weirton became a national story. It was the landmark story steel community that was fighting for its survival. A documentary called, "On Their Own Again," was filmed, showing the community trying to raise money for the ESOP. National media picked up the story; it was even featured on the cover of Parade Magazine and many nightly 
newscasts. In the 1980's Weirton and Weirton Steel become a landmark narrative (Nichols). They become the story that people remember when talking about a surviving steel town.

The Parade Magazine from December $12^{\text {th }}, 1982$, features Gate 1 on the cover with steel workers coming out during one of the shift changes. The cover headline reads, "Why They Fight to Save a Way of Life.” The title of the story is, "How the people of Weirton, West Virginia, are fighting to preserve their way of life. Can the little guys win?” (Rader 1982). The title of the article itself, paints the picture of a town striving for survival. The author takes note of the bumper stickers on vehicles and signs over the steel mill that read, "Weirton we can do it!” The article shares stories of current workers who have families and friends who have been laid off or of former workers hoping to get their jobs back if the ESOP goes through. This is an example of a narrative that is being conveyed by an outsider. Not only was this narrative being conveyed by the citizens of the community, it was also being used by many national media outlets.

When the Independent Steel Workers Union voted in favor of the ESOP. They created the largest employee takeover in the United States, and this drew a lot of national attention. It was a source of pride for some respondents to the Facebook questionnaire.

My father, two uncles, a cousin, and a grandfather all worked for Weirton Steel. It really was the pride of the city and I remember Weirton Steel making national news in 1984 when they announced the largest ESOP ever for an American company. (Male, 36)

The Facebook responses show that pride in the community and the steel mill is a main theme of both the model company town narrative and the survival narrative.

The people were the glue that kept this town together and the blood flowing through its veins. Kinder, more down to earth people you will never find, with a sense of pride as strong as the steel they produced. (Male, 48) 
This respondent not only refers to the pride of the citizens but also that the individuals in the community made it possible for the community to survive.

National news outlets picked up on the story soon after Weirton became an ESOP. ABC Nightly News had sent a correspondent to Weirton on January 11, 1984 to cover the story. Its newscast shows interviews with workers stating that Weirton is going to show the world that any community can create an ESOP if you so desire (ABC Nightly News). The correspondent focuses on how the citizens believe that they can all pull together to survive. This further pushes the narrative of the surviving steel community, in a time when other steel mills across America were shutting down. With all of the national attention Weirton was receiving, it became a landmark narrative of a steel community's survival.

The ESOP was truly the only way that Weirton Steel would be able to survive through the 1980's and 1990's. With National Steel's announcement that it would no longer invest financial capital into its Weirton Division, the citizens believed that the plant would be shut down. However, when given the chance to buy the steel mill from the company threatening to close it, the community came together to fight for survival and create the largest ESOP in the United States. Clearly, the national and local narrative of the community became one of survival, though new challenges for the surviving steel town and its steel mill were on the horizon. 


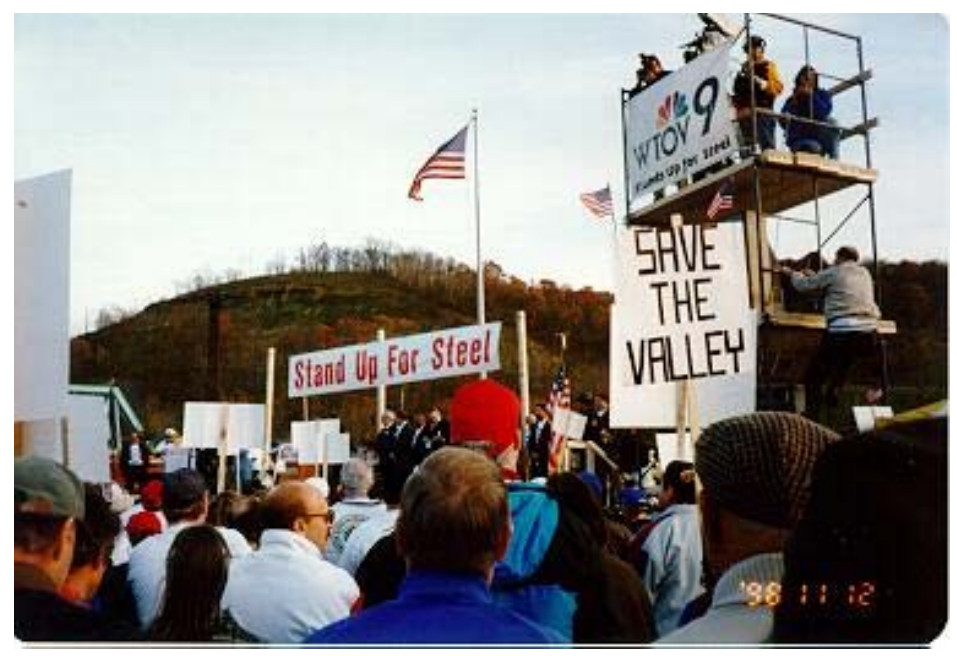

Mary H. Weir Public Library's Photographic Archives

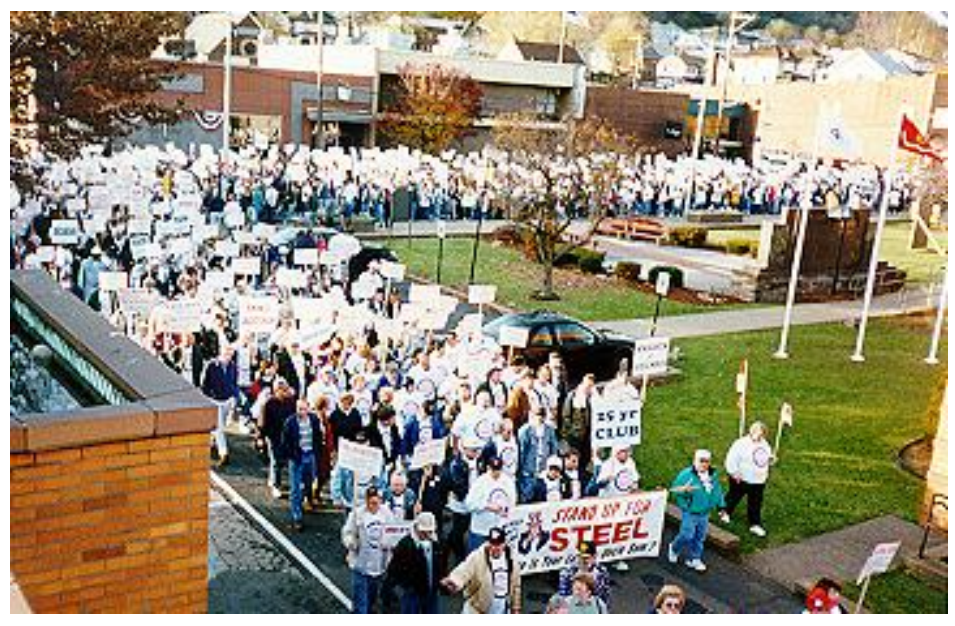

Mary H. Weir Public Library's Photographic Archives

Betrayal Narrative - “During the "Stand up for Steel" movement, I feel as though the national government turned its back on all of the steel industry. In making an effort to reach out to other nations and "create bonds" and facilitate "fair" trade, they gave up on our own nation's industries, goods and trade. If the state of our current industries and economy aren't enough proof of that, I don't know what is.” (Female, 25) 
Through the 1980s and into the 1990s foreign competition became more and more fierce (Bluestone 1982). Japan and other countries around the world started "dumping steel," which is also known as illegal foreign imports. An illegal foreign import is the term used when a country exports products to another country at prices less than what it costs the foreign country to produce them. The sole purpose of illegal dumping is to undercut domestic companies, eventually putting them out of business (Bluestone 1982). Tariffs, which are taxes on imported products, can be created or enforced to protect this from happening. Foreign imports and steel dumping helped lead to the decline of Weirton Steel.

In 2003 the ESOP, which had granted Weirton Steel survival for twenty years, was over. Weirton Steel Corporation declared bankruptcy and, in 2004, was bought at auction by International Steel Group (ISG). In 2005, ISG was bought by Mittal and, in 2006, Mittal Steel merged with Arcelor Steel, creating Arcelor Mittal Weirton. The company that was once owned by its employees had changed ownership three times after 2004 (Jones 2009 B).

Prior to the downfall of Weirton Steel, the community came together again to try to save their steel mill. Numerous marches on Washington were organized by the community in an attempt to persuade government officials to enforce tariffs and stop illegal foreign imports. The local community leaders organized a "Stand Up For Steel Campaign” aimed at getting lawmakers to enforce tariffs (Standupforsteel.com). This was once a gain a movement to try to fight for survival. However, this fight was not successful like the earlier one for the ESOP.

The story of Weirton turned into one of victimization. Weirton Steel and the community became victims. The points of reference for the shared narrative had changed. They were bound by a shared sense of betrayal instead of pride in the steel mill and the survival in the 1980s. The 
community felt betrayed by local and global forces. Weirton Steel is still the reference point in this narrative; however it became based on betrayal.

The people of Weirton felt betrayed, and many of them expressed this betrayal in the Facebook responses when asked about how they felt about local and national leadership.

The industry cried out for help for years from our political leaders, but many felt it was too important to Japan and other places for them to allow to dump cheap steel in this country and ruin one of the greatest industries in the history of the United States. It is a shame that political decisions are to blame for a towns demise. (Male, 39)

National leaders...they could care less about Weirton and the steel industry. I was in the audience when Cheney promised that he would help the ailing steel industry. I know that Clinton/Gore were here with their promises too. We're still waiting. (Female, 33)

Many of the Facebook responses point fingers at specific leaders, such as the Clinton and Bush administrations. Bill Clinton stopped in Weirton, as part of his campaign trail in 1992.

In my opinion, we were lied to by some of the national leaders of this country. Back when Bill Clinton and $\mathrm{Al}$ Gore were running for election, they came to Weirton and spoke to the community and PROMISED that they would do what they could to help the steel industry. It turned out to be political propaganda, and they did not fight so hard while in office to help salvage Weirton Steel and the other American steel industries. (Female, 24)

The political leadership and national leadership has always tried to appeal to the "union" mentality of the steelworkers and usually did nothing for them while in office. Bush was one of the worst to make promises and never fulfill them. (Male 40)

From the previous excepts from the questionnaire responses, one can see the overwhelming hostility and sense of betrayal the respondents showed while being asked about political 
leadership. While most of the anger and frustration seems to be pointed toward national politicians, some people blame local politicians for Weirton and Weirton Steel's downfall.

I think that it is a shame what happened to Weirton Steel. I think that many politics contributed to the bankruptcy, both on a local and national level. (Female 34)

Weirton was well treated by political leadership until Bush took office. Bush was one of the first presidents not to stop in WV, let alone Weirton. I don't know much about the community leadership other than to say, like most small towns, it's run by a select group of people, usually from the old families of Weirton, who tend to help their friends before they help others. (Female 25)

It is clear here that the narrative of betrayal by the local leaders, as well as national leaders, is emerging. Some are even upset by the current bailouts to the auto industry.

I find Detroit's (attempted) bailout extremely ironic-Weirton/Pittsburgh was in almost exactly the same situation 25-30 years ago, and the country lifted nary a finger to help it. Yet it survived...the same will happen with Detroit, except that it will cost our grandchildren billions/trillions. (Female, 30)

One can see from that this respondent feels abandoned or almost betrayed by the community leaders, and there is almost a bitterness present that can also be found in other responses referencing the bailed out car companies.

However, some point to a more sinister betrayer.

It seems to me that no administration (Republican or Democrat) came to our aid when the steel dumping of the 80's and 90's was in full swing. Yes, Rockefeller and Sen. Byrd helped get the ESOP project working, but no one tried to stop imported steel from taking the jobs from the valley. If you really want to know more about ESOP and how the Workers at Weirton Steel were raped read the book "BOARD BETRAYAL" by Phillip Smith. (Male 61)

In 2002 a book by Phillip Hartley Smith, Board Betrayal: Failed Governance and Management Hand in Hand with Arthur Anderson, An ESOP Fable, was published leaving new 
questions in the minds of Weirton residents. The book claims that multiple scams by the management of the company took money from the steel mill and gave it to themselves and their friends. It also points out horrible management descions, such as being represented by Willikie Farr \& Gallagher, the same law firm that defended the steel companies from Brazil, Japan, Mexico, and Canada that were responsible for illegal foreign imports. The book led many steel workers and those living in the community to feel betrayed by the leadership of Weirton Steel as well. Many of the Facebook respondents reflect this in their e-mails.

I could remember when I was younger that they would keep the Mill painted all the time, and it looked really good. But everything stems from money, pride. In the later years, the CEO's of the mill were not even from here, and they didn't care about Weirton Steel or the town of Weirton. They took all the money that they could get from the mill, and ran it right into the ground. (Male, 50)

Through the 1990s and currently the narrative identity of betrayal has set in. Weirton, once again, tried to fight for its survival; however, this time they could not pull through. Many things contributed to the fall of the Weirton Steel Corporation, including the economy, illegal foreign imports, and poor management. The betrayal narrative identity reflects these issues and the fact that Weirton and Weirton Steel had no one to help them. The community feels betrayed by the lack of government intervention and the allegations of corruption within the highest ranks of their once beloved steel mill.

\section{Chapter Three Conclusion}

By using the grounded theory framework, three distinct narratives have emerged from the data while performing a qualitative content analysis. In the 1950s the narrative identity of Weirton was that of the ideal model company town. The data shows that citizens had pride in the steel mill and the fact that they lived in Weirton and worked for Weirton Steel. The community was taken care of by Weirton Steel. Local events such as the Festival of Nations were held every 
year to celebrate Weirton's diversity. The community as a whole was even largely untouched by the Great Depression.

In the 1980s the data supports the survival narrative identity of Weirton. As the situation changed, and Weirton Steel was going to be closing, the steel workers were able to buy the steel mill and survive, while other steel mills were shutting down. A strong sense of the community coming together to succeed can be seen while examining the national and local media. Weirton even became a landmark narrative because it became the main story that national media and people outside of the community used when describing a town that survived deindustrialization in the 1980s

In The 1990s, when the steel mill was under attack from foreign competitors and would eventually have to be sold, the narrative identity of Weirton changed again. The data supports the betrayal narrative. As the community's attempts to persuade government leaders to "stand up for steel” failed and allegations of corporate corruption emerged the sense of betrayal set in to the community.

The data gathered from Weirton's history and the Facebook responses demonstrate that this community has had a collective narrative identity. As the situations in Weirton have evolved, the citizens have created new narrative identities to replace the outdated ones. Now as the situation changes again and Weirton Steel's likelihood for survival diminishes, the narrative identity of the community will have to change once more. 


\section{Chapter 4: The Future Narrative Identity of Weirton}


In the previous chapter I discussed how Weirton has had a narrative identity, revolving around Weirton Steel, since the company was founded. In this chapter, I propose that the community will have to find a new narrative to use as a sense making practice to what is going on in Weirton. I will give information about the Facebook group and the data gathered from observing online interactions between the group members. Finally, I discuss the data from the survey distributed to the Facebook group, which shows the emergence of three possible future narratives (1) a ghost town; (2) a bedroom community of Pittsburgh; (3) a new industry will develop in Weirton.

Steel is no longer being produced at Arcelor Mittal Weirton; it is now only a finishing mill. Steel is imported from other companies and Weirton puts the finishing coat on it. Weirton Steel once employed 14,000 people and now it only employees 928 union workers. The population of Weirton is now 18,748. The community has been devastated without the support of Weirton Steel and the responses from the Facebook group survey show the devastation.

After performing preliminary analysis and asking individuals what they believe lies in Weirton's future, three narratives kept emerging as possibilities. The first likely scenario is that Weirton's new narrative will be that of a ghost town. This is more of a pessimistic view of Weirton's future; however, some believe that Weirton will not be able to survive without Weirton Steel. This narrative reflects towns that have also been decimated by deindustrialization, such as Flint, Michigan. These narratives can also be viewed in the Western parts of the United States, where many gold mine towns have been abandoned after the Gold Rush.

The second likely narrative of Weirton is that it will be able to attain a new industry and maintain its significant independence. Many people I talked to during preliminary research 
pointed out that Weirton has great infrastructure and great location. US Route 22 runs through the city and it is situated right beside the Ohio River. There has recently been discussion of a new port facility being built in Weirton, but no one is sure that it will happen.

The third likely narrative identity for Weirton that emerged while doing preliminary analysis was that of a bedroom community of Pittsburgh. Weirton is only a 45 minute drive from Pittsburgh; therefore, many see its future as a suburb of Pittsburgh. While many believe that this is a good thing, others tend to have more of a pessimistic view of being Pittsburgh's suburb, and some think that it is the only way the community can survive.

\section{About the "I am From Weirton, WV" Facebook Group}

In order to find out how current and former citizens feel about the next possible

narratives of Weirton I have Facebook as the main resource; specifically, a group on Facebook called, "I am form Weirton, WV." The Facebook group is composed of members from who currently live or have previously lived in Weirton. It is even composed of people who lived in neighboring communities who spent a lot of time in Weirton. There are currently over 2,000 members in the group. The group's description, which is written by the creator, is, "Finally a group for all of the folks from Weirton, WV for Facebook. Show that Weirton pride and share some memories of our hometown!”

The group members frequently post their memories on the group's wall, some post pictures to the group while others have even included a video featuring a drive through of the community. Some members talk about how the city has declined.

In the very near future Simmons Furniture and LaPostas will join the list of things that are no longer in Weirton. You can not buy a 2010 vehicle in this town, all the dealerships are closing or selling used vehicles. No furniture stores either. (Male) 
Others post about how much they miss old establishments in Weirton, community activities, or would like to come back to the community if they could.

I'm not from Weirton myself, but my father was and growing up, we spent at least a week or two in Weirton every summer. Haven't been back in a few years and I really miss it and my family up there! (Female)

Even people who only had family in Weirton and have not lived there have joined the group. A lot of them miss the community and would like to return. Other posters have commented that they have had to leave the community for work, but return to visit whenever they get the chance. Many posters ask for input from others, for example, if they can remember the old hamburger joints or establishments that have closed.

Some of the posters have mentioned gambling on the open forum.

If any of you live in Ohio, vote Yes on Issue 3. We need casinos to bring 34,000 new jobs to Ohio, along with millions in tax revenues. Yes, I am working for Issue 3. (Male)

Another poster responded:

34,000 jobs - you're kidding, right?? Our wonderful casinos got us a lot of folks with gambling problems, but not so many jobs. (Female)

This open forum is also used for some minor debate such as the one posted above. Some of the posters think that gambling is good for communities; however, most post negatively about the new cafés that have opened in the area. A Café in Weirton usually means a gambling establishment. There is even a discussion titled, "Should Weirton Change its Name”, in which one respondent replied, “Weirton Café and more.” 
It seems as though the main purpose for this group is for current and former residents of Weirton to be able to come together and share their memories of the community. As soon as one member posts memories of a favorite place in Weirton, many others respond with similar memories of the place. Others post their regrets about Weirton, expressing the feeling that something, which was once great, is lost. Some posters respond similarly and discuss the fate of businesses they used to enjoy and how the town is not as great as it used to. Most of the posts, however, reflect the positive memories people have of Weirton.

A lot of these memories can be seen in the discussion topics of the group. A member can create a discussion topic and others can respond to that topic. There are over 27 discussion topics with people adding their own post to each of the topics everyday. The most active topic in the discussion section of the group is, "Things that are not in Weirton any more (and you wish they/it were) ...”. This further shows that people are using this group to come together and talk about Weirton and the memories that they have.

Hey, I remember going to Winkey's with my dad every pay day to buy dinner and take it home. Also remember the Red Rose Inn, they had a restaurant there and we would go to breakfast on Saturdays. Boy, the good old days! (Female)

Many of the posts are similar to this. They go into great detail describing exactly what they miss in Weirton. Some of the respondents even mentioned that they miss Weirton Steel. Another popular discussion topic was, "Why are you proud to be from Weirton?” A lot of posters mention the fact that they came from a safe community that was able to instill a hard work ethic in them, and others mentioned the diversity and friendliness of the community. Some mention that they have never been able to replicate the friendships they had found in Weirton in any other community. Other posters mention that they are proud of the community because: 
Through thick and thin Weirton always seemed to pull together and help the less fortunate. When King's Creek flooded the town would embrace the victims and the citizens would open their spare time to help the victims of the flooding. When WSX was about to fold in the 1980's the people of Weirton pulled together and made the difference to keep the mill running. (Male)

Being proud of the community for hard work ethic, diversity, and community ties are the main reasons that group members cite as why they are proud to be from Weirton.

The Facebook group also features a collection of around 50 photographs, some of which can be seen in the appendix, that members of Weirton have posted. Some are pictures of famous athletes that have come from Weirton and others are of family members from the past. A lot of the pictures are of what Weirton looks like today, due to the fact that many members of the group are former residents of Weirton and are usually interested in what the community presently looks like. There are also many pictures of Weirton from its earlier years. There are pictures of the steel mill, Main Street, pictures of old schools, and an old hospital that was once in the area.

The majority of the group is proud to be from Weirton; however, there is the occasional wall post from younger members who express their urge to leave the city. The majority make up of the group is members who reminisce about the good old times and try to find other members of the community who feel the same. There are members who are still living in Weirton and post pictures and talk about what it is like today for the citizens who have left. The group works as a tool for Facebook members from Weirton to be able to come together to share memories with each other.

\section{Data}

As mentioned earlier, by contacting the creator of the Weirton group I was able to send out a mass message, containing a survey, to all of the group members. The eldest one who 
responded was 72, while the youngest was 18. Most of the respondents did not live in Weirton anymore. One would expect this due to the economic conditions of the community without Weirton Steel. The majority of the respondents believed that Weirton would become a bedroom community of Pittsburgh; the next highest response was that it would become a ghost town; and only a few believed that Weirton would develop a new industry. Some people answered that they were unsure of what was the next chapter in Weirton's history, and a smaller number believed it would be a mixture getting a new industry and becoming a suburb of Pittburgh.

While reading through the data using the grounded theory framework, one can sense either a level of optimism or pessimism in the respondent's answers. Some people answered whether they were optimistic or pessimistic, while others expressed their optimism or pessimism in vivid descriptions of what they believe will happen next in Weirton's future or what is currently happening in Weirton. The optimism and pessimism dimensions are important for seeing if people believe Weirton will become a bedroom community of Pittsburgh or develop a new industry. Obviously, optimism is not such a factor in the possible ghost town narrative. However, the respondents have different thoughts and feelings as to whether Weirton becoming a suburb of Pittsburgh is a good thing or if they feel that it is negative because Weirton will lose its identity and independence.

The histories of the respondents are very similar. The ones who have left Weirton mainly cite leaving the area because they needed a job. Some lost their jobs in the mill while others moved away after graduation from college. 94\% of the people who responded to the questionnaire worked in Weirton Steel or had immediate family members who worked in the steel mill, showing how connected Weirton Steel is with individuals in the community. 
In response to my request for community memories of individuals, many talked about the friends that they had in Weirton and the amount of diversity in the city. One of the most popular memories was that of the ethnic food festivals that Weirton had in the community every summer. They also talk a great deal about the community ties: "The feeling of community. The multiple cultures all merged and there is a feeling of acceptance..” (female, 55).

I also love the feeling of community that came along with growing up in Weirton, especially Friday and Saturday night high school football games. I also remember feeling very safe and care free growing up in Weirton, and I think about that often. I am very proud to be from Weirton, WV. (Female, 34)

The sense of community and feeling safe as a child is echoed throughout most of the memories along with the International Food Festival that Weirton had. Every respondent, with the exception of two, had fond memories of the community. The two respondents who had negative memories discussed the pollution in the city and decided to leave to find a nicer looking place to live.

Corresponding to the three emerging and competing narratives, the grounded theory approach exposes four groups of story tellers from the collected data. The first is the Ghost Towners. All of these respondents have a very negative outlook on Weirton's future and were very pessimistic about becoming a bedroom community of Pittsburgh or being able to develop a new industry. They all had major themes in their responses including, gambling problems, crime, infrastructure, drugs, and changing community values.

The second group of future narrators are the optimistic Bedroomers. This category reflects optimistic attitudes and hope that the community can become a suburb of Pittsburgh. The main themes in this group’s responses were river access, city beautification, less pollution, and developing a service industry. There were also some negative Bedroomers who believed that 
being a suburb of Pittsburgh was its only hope for survival or that becoming a suburb of Pittsburgh was not enough to sustain the community.

The final narrators are the Revitalizers. They believe that the community has a chance to develop a new industry now that Weirton Steel is out of the picture. Common themes from these individuals were river access, highway route 22, and a hard working workforce. Some also believe that the gambling industry can be further developed and Weirton could become an “Eastern Las Vegas.” These individuals tend to be optimistic, although some are cautiously optimistic.

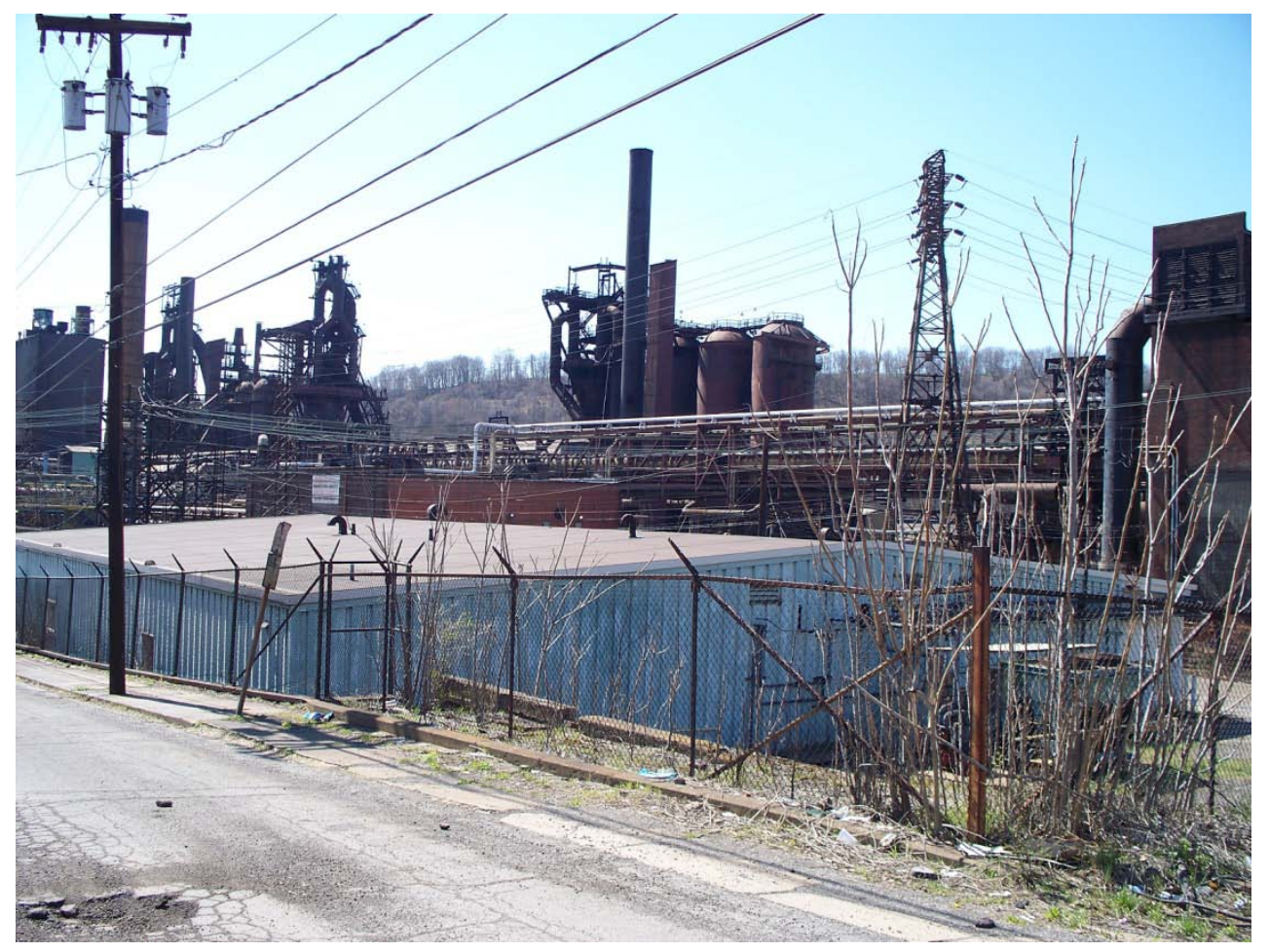

Jason Rine

Ghost Towners - "Some of my favorite spots are now sad little gambling pits. When Weirton lost the Dairy Queen across from Sheetz, I lost all hope.” 
I will begin my analysis of the respondent narrorators with the group that I call the Ghost Towners. The Ghost-Towners have a negative view of the community and its next chapter. This category or group was created by continuous patterns that I noticed in the data. The Ghost Towners not only said that they believe Weirton will become desolate, but they also all had similar themes behind why they believed so. There was also a pattern of desperation that surrounded their responses; they seem to believe that nothing can save Weirton without Weirton Steel. Their responses are overall very pessimistic in nature, so even if they do not identify themselves as pessimistic, it is possible to code them as such due to the consistent patterns that emerge.

Most of the Ghost Towners are younger than the other respondents and if they have not already left the community they state that they are on their way out. Some of the main themes that are abundant in the Ghost-Towner group were: gambling problems, drugs, nothing to attract young people, higher crime rates, lack of jobs, and a lack of infrastructure. A common theme throughout the Ghost Towner's responses was that Weirton Steel was the great fabric that held the community together and without it the city will not last.

I feel like the mill was the heart and soul of our community. So many of our friends and relatives made their lives working there and it saddens me to see it all lost. It's the end of an era. I don't know that we will ever see the productivity and the livelihood the steel mill once offered from either a shipping port or a "new business" community. (Female, 40)

Responses such as this are very similar in all of the pessimistic responders. One can feel the lack of hope in the Ghost Towners responses due to the fact that they believe that there is not an industry that can save the community. 
The mill looks like a skeleton of what once was the symbol of the city. Now it is a reminder of what everyone has lost. I am very pessimistic of the future of Weirton. (Male 39)

People are viewing Weirton Steel as the symbol of the community; now all that remains is its skeleton. Again, one can see the common theme of a great loss that the community has suffered.

The majority of Ghost Towners left Weirton because they have not been able to find a job. The younger ones talk about better opportunities in other parts of the United States and the older ones discuss how they had to leave the community in order to find work.

Personally, I grew up with the mentality that I never wanted to live in an area where I could just live the quiet simple life and make ends meet. I felt as if there was more I wanted to ensure for myself beyond that including financial security and a higher quality of life in general. Moving away from Weirton to Atlanta, GA was one of the best life decisions I made. (Male, 26)

This is another common theme that was present in most of the Ghost Towners who left the community. They feel as though they had no reason to stay and they felt that they could have better lives elsewhere. Even though not everyone who left Weirton for a better job was a Ghost Towner, many of the Ghost Towners have left or are on their way out. Many of the Ghost Towners also state that because the younger generations are leaving the community, the only population left in Weirton will be the retirees and the elderly who cannot leave the community.

Some of the younger Ghost Towners talk about how there are no jobs and nothing in Weirton to entertain them.

Last summer, while I was at home, I went job hunting and the most common answer I got was that the place could not afford to hire me. I don't like going home because there's nothing to do and there's no one there anymore, all of my friends have left. I really do have a pessimistic viewpoint when it comes to Weirton. (Female, 20) 
This response reflects the fears of most of the Ghost Towners. Here we have a 20-year-old who not only feels like she cannot find a summer job in Weirton, but also states that there is nothing in Weirton to do. Common themes have emerged, such as lack of entertainment and no jobs.

This emphasizes what most of the older Ghost Towners have said about the community's chance to become a bedroom community of Pittsburgh.

I am pessimistic about this (becoming a suburb of Pittsburgh) coming to fruition as I see little being done to bring businesses into the city. People are willing to pay higher taxes and more for real estate in order to have a good life. Unfortunately, Weirton has little to offer in the way of entertainment for families (Female 51).

As I will discuss later, many Bedroomers have suggested that lower taxes give Weirton the best chance to become a suburb of Pittsburgh; however, some respondents believe nothing in Weirton will attract young commuters.

The Ghost Towners that brought up gambling in the area all referred to it as something that was hurting the community. None of the Ghost Towners believed that gambling could bring anything positive to the area.

The city once booming in population of families of steel workers has since moved to a city now booming in gambling. Instead of being known for hard workers earning an honest living Weirton is now known for an addiction to gambling that empties the pockets of the hard working which has caused hard times for many and caused an increase in the crime rate. (Male, 26)

One can see the transition that this Ghost Towner believes is happening. This is echoed throughout many of the pessimistic responses that reference gambling. The patterns emerges that gambling and the addiction to gambling that the establishments create will result in Weirton becoming a ghost town. Many respondents also link the gambling to a perceived increase in crime rate in Weirton. 
Many of the Ghost Towners also reflect on the values that have been taken away from the community by the gambling establishments.

We have made a big switch from a family oriented town to a casino joint. You now read headlines about Little Las Vegas ice cream parlors are now Cafes, the Dairy Queen and Brusters are now places where Daddy can lose his son or daughter's college fund in a hope to get rich in this failing economy. (Female, 25)

The common themes of lost values and lost sense of community can be seen throughout the pessimistic responses. Many of the individuals who mention gambling bring up the iconic Dairy Queen or Brusters which were the main ice cream parlors in Weirton. Dairy Queen and Brusters have been closed in order for video gambling establishments to be put in. These individuals believe that the gambling establishments have taken over the town.

The multitude of gambling establishments without any architectural/zoning plans has hurt the appearance of Weirton. Each time I travel back home, it depresses me to see how, despite the smokeless skies, Weirton can't compare to the beauty and charm of smaller towns I've visited. (58, Female)

The Ghost Towners who oppose gambling also comment on the aesthetic appearance of Weirton. They believe that not only has gambling hurt the values and people of the community, but it has also taken away from its aesthetic character. Every Ghost Towner who brought up gambling has responded in similar ways, exposing this pattern in their responses.

Other Ghost Towners bring up drugs and crime as other reasons why the community will become and is heading toward a ghost town.

A lot of us who went away from the town learn of passing of people we went to school with - overdosing on some type of drug whether it is heroin or prescription pills. This alone is tearing down our city - adults selling drugs to minors, minors selling drugs to minors, minors selling drugs to adults, and so on. (Female, 23) 
Some of the younger Ghost Towners mention that they know someone who has died, is addicted to or selling illegal drugs. Many of the older ones describe how, "Main Street is the new place to score hard drugs.” Through out the responses of the Ghost Towners who mention drugs, many of them again point out that Weirton was once great but now is in steady decline. They use the drug problems as a way to express their pessimism about the community.

Another common theme that appears amongst the Ghost Towners is the lack or deterioration of infrastructure. Some state that, due to the mill closing and the loss of tax revenue, Weirton has not been able to keep up on maintenance on the community's infrastructure. This is also one of the reasons why the Ghost Towners often say that it cannot become a bedroom community of Pittsburgh. The lack of good infrastructure and the overall aesthetics of Weirton, they believe, will keep the younger generations away.

The Ghost Towners also make comparisons to the past. They talk about their memories of how great the community once was, going into great detail about high school homecoming parades from a few years ago and what they are like today. Many Ghost Towners mention that the sense of community among Weirton is disappearing and citizens are losing their hearts. They believe that the population has more or less given up on the community without the steel mill. One even makes a comparison to surrounding communities.

As a parallel one only has to look up river to the towns of New Cumberland, Newell, Chester, and East Liverpool. Brick making and pottery were the heart of these towns and there has been no comeback yet (Male 65)

This Ghost Towner also believes that similar events are unfolding in Weirton due to the life of the community being shut down. It seems to be a common theme present in many of the Ghost Towner's responses. 
Other Ghost Towners believe the city officials are not moving forward in order to replace the void left by Weirton Steel.

Well in regard to leadership in Weirton, I think it has been lacking in so many ways. It seems to me that there are people in the community who own land and who don't want to sell it to help the city grow. I'm sad when I don't see the effort being made by our so called leaders to attract new business to the city. Weirton had depended on Weirton Steel for far too long and now that it's going away and has been for 25 yrs. (Male, 38)

A lot of the Ghost Towners believe that Weirton officials are not doing enough to help usher in new business and some of their policies are even hurting the chance of a new business coming to town.

Many of the Ghost Towners realize the manufacturing economy of the United States is disappearing and that a new service economy is taking place. However, the service economy cannot provide the wage that the industrial economy provided.

My pessimistic feeling is that Weirton will continue on like many other dead towns across the country, whose economy is pretty much Domino's Pizza, McDonald's, and Wal-Mart. (Male, 35)

One respondent even says, "Ironically, a new Super Wal-Mart is being constructed on the site of the old Weirton Steel general offices on Three Springs Drive.” This is ironic because at one point, Weirton Steel was the largest employer in West Virginia and now it is Wal-Mart. This is almost a symbol that the industrial age has come to an end and Weirton is entering the service economy.

The Ghost Towners made up the second largest group of the respondents. Their narrative includes the common themes of desperation, abandonment, criminal activity taking over, and loss of heart. Though many of the Ghost Towners were younger, there were older ones who have 
left the community as well. All the young Ghost Towners are eager to leave Weirton because of the lack of jobs, the lack of entertainment, or the perceived drug issues. Many of the older Ghost Towners have already left.

The Bedroomers. “It isn’t bad to be a just a sleepy town where families can be raised.”

The next group of story tellers that emerged from the data is a group that I have named the Bedroomers. This group is extremely diverse; they are made up of both males and females and come from many different ages. The common themes that emerge are: highway access, waterway access, low property taxes, and proximity to Pittsburgh. Some of the Bedroomers view Weirton Steel's downsizing as an opportunity and others view becoming a suburb of Pittsburgh as Weirton's only hope. There are different levels of optimism and pessimism throughout their responses. The group splits into optimistic bedroomers and pessimistic bedroomers.

The optimistic bedroomers were usually individuals who still reside in Weirton. They mention a variety of things as to why Weirton is going to become a bedroom of Pittburgh and why they believe it is going to be good for the city. Some of the optimistic Bedroomers believe that Weirton is already a suburb of Pittsburgh and can further benefit from that status. Many of the Bedroomers believe that the community should embrace becoming a suburb of Pittsburgh.

It is the small town America which folks like when looking for a place to live. It's not about being able to find the job our grandfathers had in the city but being able to preserve the city as a slice of West Virginia heaven where hometown rivalries still duke it out and kids can enjoy safe neighborhoods. I think that politicians are wary about jumping on this sort of bandwagon because people want to hear how jobs will be brought to the city. Preserve the businesses we have, when we can make it easier to grow or bring business here, do it. But it is important to look beyond what we are currently dealing with and not dwell on the past. (Male, 23) 
Many of these themes can be seen throughout the other responses. This Bedroomer believes that becoming a suburb of Pittsburgh is something that the leaders should embrace but are not willing to. Other common themes that emerge are that of being in a safe community and being an enjoyable place where people would like to live.

Many bedroomers believe that there is an opportunity to beautify the city and make it an attractive place for commuters to Pittsburgh to live.

I think that Weirton is on its way to becoming a suburb of Pittsburgh. I don't think that is a bad thing at all. If the right folks get some money for this town, it could be a great recreational area. Maybe tear the mill out that hasn't been and won't be used. Clean up the area around the Ohio River and who knows, it could be a beautiful place. (Female, 50)

This response has themes that reflect many of the respondents who view Weirton as a suburb of Pittsburgh. They do not view becoming a suburb of Pittsburgh as bad and they feel the community should embrace it. Many of these respondents also refer to cleaning up the city and tearing down the old parts of the steel mill that are no longer in use. They seen an opportunity to tear down the old parts of Weirton Steel and begin renovating the community along the Ohio River to create an attractive area for people who would like to live in Weirton and commute to Pittsburgh.

Some of the respondents state that Weirton is already a suburb of Pittsburgh and the city officials just do not realize it yet.

Weirton needs to look ahead, it has been a bedroom community for Pittsburgh for a long time, but no one wants to admit it. Steubenville has had billboards up on 22 for a long time singing its praises as a bedroom community. (Male, 50) 
This respondent brings up an excellent point that is in some of the bedroomers responses. When watching a Pittsburgh channel one can see commercials for Steubenville, Ohio, just across the river and further away from Pittsburgh, calling itself the, "The Burb of the Burgh.” Many of the responses indicate that the community has yet to accept its role as a suburb of Pittsburgh, as Steubenville has.

One of the main reasons respondents think that Weirton will become a suburb of Pittsburgh is because of a lower cost of living and property taxes. This theme is present throughout many of the Bedroomers' responses. They believe that lower taxes and cost of living, compared to those of living in Pittsburgh, will attract commuters who will have jobs in Pittsburgh.

Some of the Bedroomers believe Weirton's close location to Pittsburgh and US Route 22 will lead to it becoming a suburb of Pittsburgh. They cite that highway Route 22 connects Ohio to Pennsylvania and runs right by the city of Weirton., which is only 32.9 miles away from Pittsburgh.

Personally, I don't think it takes much longer to get to the city from Weirton, than from many Pittsburgh suburbs, for example, Bethel Park or Beaver County. I don't think people realize how close Weirton actually is, maybe they can't get past that it's in another state. If Weirton had some kind of public transportation into downtown and marketed itself as a suburb of Pittsburgh, maybe it would see a population increase. (Female, 31)

Many respondents realize that Weirton is in close proximity to Pittsburgh as all of the other Bedroomers do. Many other Optimistic Bedrooomers have mentioned that Weirton should market itself as a suburb of Pittsburgh as well as create public transportation to the city. A lot of the optimistic Bedroomers' believe that the community leaders need to take steps in order to solidify the community's identity as a suburb of Pittsburgh. 
Some of the Positive Bedroomers cite construction projects in Weirton as ways that will help make it a suburb of Pittsburgh. A new project is being developed around Colliers Way and a new Super Wal-Mart on Three Springs Drive, which respondents believe can attract people who want to live closer to Pittsburgh

I think Weirton will survive. As a 50 year resident I've seen Weirton continue to transform. It may take 10 years or more, but I honestly believe being close to Pittsburgh will help bring even more development to our community. We are already seeing some new development with a new hotel and developing areas for upcoming stores and housing. So construction is presently happening and Weirton is continuing to transform as it always has. (Male, 50)

Some of the Bedroomers mention the construction that is happening around Weirton as a sign that the community will continue to thrive and transform into its next chapter.

The Pessimistic Bedroomers tend to be individuals who have already left the area. They believe that Weirton's only hope for survival is becoming a suburb of Pittsburgh. They discuss a variety of reasons as to why Weirton can become a suburb but they also mention the obstacles in the way to becoming a suburb of the community. One can sense a feeling of hopelessness in their responses.

My money is Weirton becoming a bedroom community of Pittsburgh. Low taxes, low cost of living and available housing will keep this old steel town alive for a while. Weirton's future is not bright at this moment in time. The loss of industry $\&$ taxes means this town will not be able to maintain its infrastructure. The decline is evident to those who return to Weirton from time to time. (Male 50) Many of the Negative Bedroomers have similar common themes. They believe that is not good enough for Weirton to rely primarily on becoming a suburb of Pittsburgh. As the following respondent points out, Weirton is losing its main tax payer and she believes the infrastructure will fall without Weirton Steel. 
I have a pessimistic view of Weirton's future. It will be a bedroom community to Pittsburgh if we're lucky. (Female, 32)

Some of the respondents replied by saying that Weirton will become a suburb of Pittsbugh; however, they have a pessimistic view of Weirton's future. A commom theme of Pessimistic Bedroomers is that Weirton's only hope for survival is to become a bedroom community of Pittburgh.

Many of the Bedroomers see the new development, such as the Colliers Way project, as a sign that Weirton is coming closer to becoming a suburb of Pittbugh. There is a new project underway in Weirton, which is reportedly building shopping centers around the Weirton Medical Center and the new Super Wal-mart that is currently being built.

Without some innovative community leadership, Weirton's best hope is to be a bedroom community of Pittsburgh. The areas serviced by the two US Route 22 exits (Colliers Way and Three Springs Drive) closest to Pennsylvania are most likely to benefit. They are already being developed into retail areas that serve the greater community. The hospital is also located in the Colliers Way area. The residential areas near these exits provide the closest drive to Pittsburgh. Although I believe Weirton can survive, it has very little chance of returning to the prosperous community it once was. (Femlae, 49).

Many of these themes are expressed throughout the Bedroomers' responses. The Bedroomers believe that Weirton will become a suburb of Pittburgh because of US Route 22, which leads right to Pittburgh, and the new retail development. Another common theme amongst the bedroomers is that Weirton will not return to the glory days of the past.

The Bedroomers, as noted above, are a very diverse group. They are men and women from all different ages and they all have different stance on what it would mean to become a suburb of Pittsburgh. Some believe that Weirton could benefit from becoming a suburb of Pittsburgh, while others lament that status is not good enough for the local economy. The group 
was almost split down the middle in regard to being a suburb of Pittsburgh was good for the community or bad.

\section{The Revitalizers - "The next chapter of Weirton can be a bright one. With the freeing up of property once owned by WSX, there is more room to grow."}

Only about $11 \%$ of the respondents said that they believed that Weirton would get a new industry and that the community had an opportunity with the downfall of Weirton Steel. The majority of the respondents who were Revitalizers tended to be older. Some were very optimistic and others were cautiously optimistic. Many of these respondents still reside in the community. There were many common themes that emerged from this group. They believed that Weirton had the opportunity to develop land where old Weirton Steel buildings still stand, they stated that the community and riverfront could be beautified to attract new tourism, that gambling could be further developed, and that the highway along with river access could bring a potential new industry or industries.

The main reason the Revitalizers believe that Weirton will attract new business is because of Weirton's location along the Ohio River and that a major US highway runs right through the community.

Weirton just needs to think out of the box a little. The potential for a new future is all around them. The combination of rail, river, highway and a solid work force makes the area a natural for business. Weirton will most likely never see large employers like the mill but 20 or so small operations will make a difference.

Most of the Revitalizers echo the same common themes throughout their responses. They feel that Weirton has all of the amenities a new manufacturer would need to start up. Many of the Revitalizers do not believe that Weirton will have one business but many smaller ones that could create jobs throughout the area. The river access, the highway access, and railroad access are all 
common patterns that have developed throughout the Revitalizer's responses. Other patterns that emerge are: the work force, tourism, and gambling.

Even though most respondents say Weirton will revitalize and become strong on many businesses, there are a few optimistic ones that believe that a new big business could, someday soon, call Weirton home.

I believe, due to the extreme convenience of the shipping channels such as the river, train tracks, and highways, Weirton will someday be developed back into an industrial hot spot. The vast amount of land that will be available and at a "relative real-estate" song will make it irresistible to many. (Male, 44)

Another respondent says that he optimistically believes one day a car manufacturer could come and build a plant in Weirton due to its location and ability to transport goods throughout the United States via river and highway.

Other Revitalizers see an opportunity for Weirton now that Weirton Steel is out of the picture. The main thing that they believe Weirton should focus on is the beautification and development of the riverfront for tourism.

Weirton should somehow make use of its waterfront on the Ohio River to bring in tourism. For example, speedboat racing and fishing tournaments would bring in dollars and media exposure, i.e., ESPN. Purchase waterfront real estate from local industry to develop a boardwalk with retail businesses and town homes. (Male, 51)

The common theme of beautification carries through many of the Revitalizers, who believe that a developed riverfront and an attractive location will help spur the economy.

A smaller number of Revitalizers look toward gambling as the new industry that can save Weirton. They believe that along with beautifying the city and expanding the gambling industry, 
Weirton can become a gambling tourist attraction that can generate jobs and revenue throughout the city. They see gambling as an opportunity for Weirton to grow.

Will Weirton spawn a new industry? New is relative to whom you are asking. The gambling is new to my generation but not really new to yours. The answer is yes and it is the gambling industry. The valley has been targeted to be a small Atlantic City for at least 30 years. Slowly but surely the gambling industry will continue to grow allowing Weirton and the area to grow with new jobs and visitors coming to play.

Many people also see the closure of Weirton Steel as an opportunity to grow and develop the community.

The next chapter of Weirton can be a bright one. With the freeing up of property once owned by WSX, there is more room to grow. Weirton hasn't grown because WSX never wanted to sell the property around the GO, or even disassemble Brown's Island Coke Plant which has been idled longer than the blast furnace. (Female, 30)

The common theme of freeing up of land that Weirton Steel once owned is throughout the Revitalizers responses. Some of them talk about developing a big gambling establishment, and a few others mentioned building an amusement park around Brown's Island which could help spur the economy. The Revitalizers see opportunity to develop land that is left vacant by Weirton Steel.

Many revitalizers believe that Weirton has the opportunity to continue to grow. Some have realistic thoughts while others seem overly optimistic. Most of the Revitalizers still live in the community and they tend to be older respondents than the Ghost Towners or the Bed Roomers.

Only a few said that they believe Weirton would gain new industry and also become a suburb of Pittsburgh. They are almost a hybrid group of the Bedroomers and the Revitalizers. 
I believe Weirton is going to become a couple of these things. I feel very optimistic about our future. I look to Youngstown $\mathrm{OH}$ and how its steel mills closed and things were bleak, but if you look at Youngstown today, it is a thriving place. I believe we will get new business and industries here (as we have started to do already) and I also believe as more and more people from PA start to look at how close we are to Pittsburgh, the fact is MUCH cheaper to live here, they will come here to live and work in PA. (Female, 50)

This was a more positive group and had common themes of being close to Pittsburgh and comparing Weirton with other communities who have faltered but have made a comeback.

In summary, while examining the data one can see three distinct groups of narrators that emerge: The Bedroomers, the Ghost Towners, and the Revitalizers. The Ghost Towners are extremely pessimistic, the Bedroomers have both optimistic and pessimistic common themes, and the Revitalizers have mostly optimistic patterns. I have identified three corresponding narratives that I believe are emerging in Weirton, and one will eventually take hold as the major narrative: the bedroom community of Pittsburgh, the ghost town narrative, and the new industry narrative. 


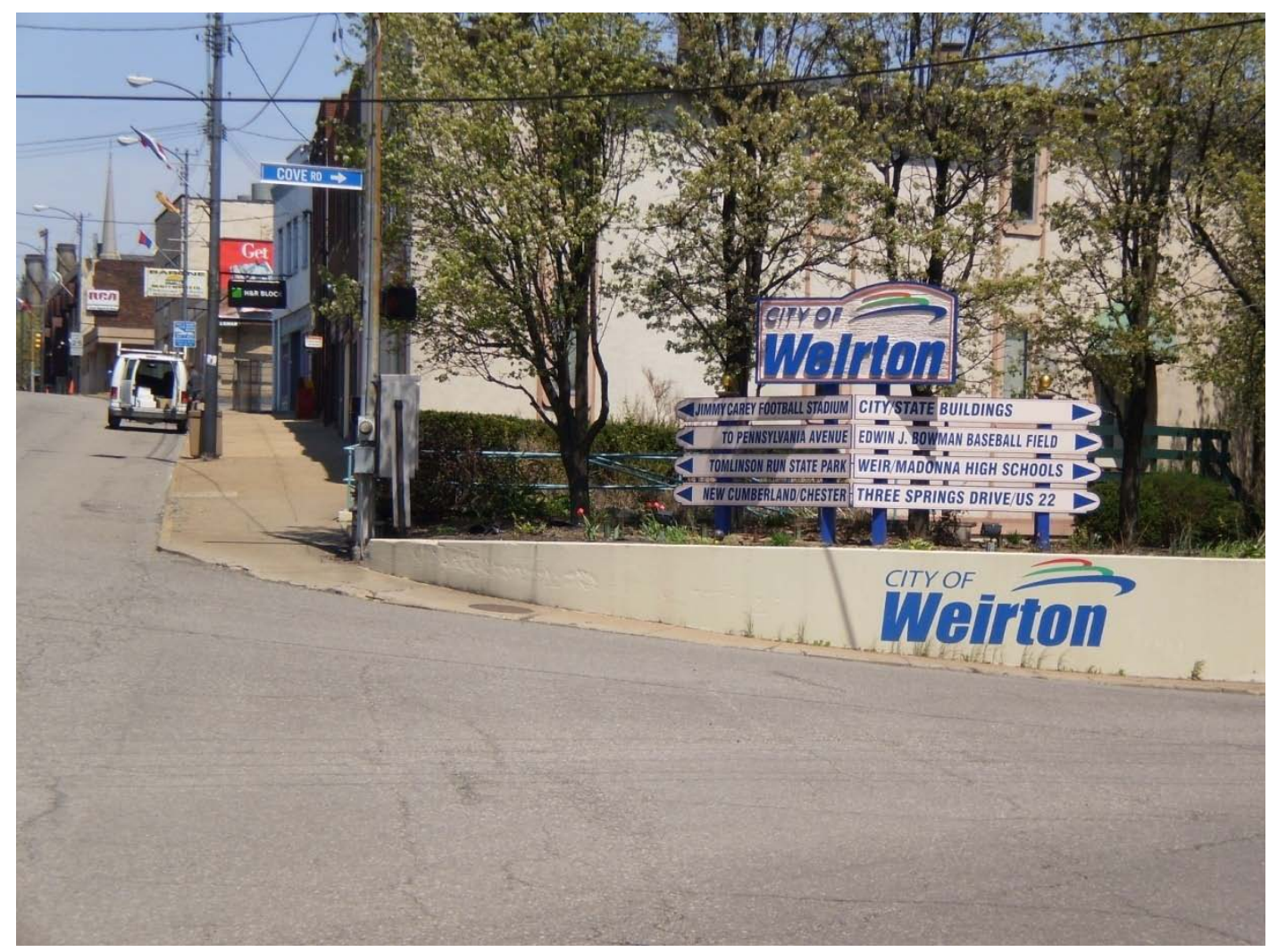

Russell Rine

Chapter 5: Findings and Conclusion 
In Chapter Three I showed that Weirton has had a shared narrative with Weirton Steel throughout the community's history. The citizens of the community were linked with the steel mill through all three narratives. They were united by the mill when it first opened until the 1980s; Weirton was the model company town. The mill was the heart and soul of the community and the workers refused to join national unions. In the 1980s the community came together to purchase the steel mill, enabling it to survive, which in turn created the survival narrative. Finally, the betrayal narrative still linked the community with the mill, because they were fighting to keep Weirton Steel alive. While analyzing the data in Chapter Three one can find support for the conclusion that there has been a shared identity which is connected by certain narratives.

This study has shown, by using the grounded theory approach, that throughout Weirton's history there has been a shared identity which has been rooted in narrative. In the fourth chapter I have gathered data to discover whether Weirton will continue to have a community narrative identity once Weirton Steel is no longer in the picture. The data shows that Weirton will continue to have a narrative identity; however, there is a question of which of the three it will likely be. Will its narrative be that of a ghost town, a revitalized industry or a bedroom community of Pittsburgh? One of these three narratives will be the identity, which is rooted in narrative; it is just a matter of time before one takes hold. The data has showed that there are four distinct groups that emerge. Below is a chart to summarize and the characteristic and the major themes of each category. 
Table 5.1

\begin{tabular}{|c|c|}
\hline Group & Characteristic /Major Themes \\
\hline Ghost Towners & $\begin{array}{l}\text { - have left Weirton or plan on leaving } \\
\text { - See no opportunity in Weirton } \\
\text { - View gambling as part of the problem }\end{array}$ \\
\hline Pessimistic Bedroomers & $\begin{array}{l}\text { - Becoming a suburb is the only hope or } \\
\text { is not good enough. }\end{array}$ \\
\hline Optimistic Bedroomers & $\begin{array}{l}\text { - See Opportunity to attract younger } \\
\text { people who would commute to } \\
\text { Pittsburgh }\end{array}$ \\
\hline Revitalizers & $\begin{array}{ll} & \text { still living in Weirton } \\
\text { - } & \text { Believe new industry or industries will } \\
& \text { come to the community. }\end{array}$ \\
\hline
\end{tabular}

The grounded theory approach allowed the data to create the categories for the analysis in Chapter Three and created the groups of individuals for Chapter Four. The historical documents were viewed with the grounded theory approach, and by doing line by line and axial coding the three historical narratives of the model company town, the survival narrative and the betrayal narrative became dominant. The fifth chapter pulled from the responses of the individuals to create four categories of Facebook members.

After analyzing the data, three groups have emerged: the Bedroomers, the Ghost Towners, and the Revitalizers. There were Bedroomers who were pessimistic, however more seemed optimistic. The Ghost Towners were all pessimistic, and the Revitalizers were all optimistic. One can put these three groups into on a qualitative quadrant scale of pessimism and optimism, along with opportunity. 


\section{Figure 5.1}

\section{Optimism}

No Opportunity

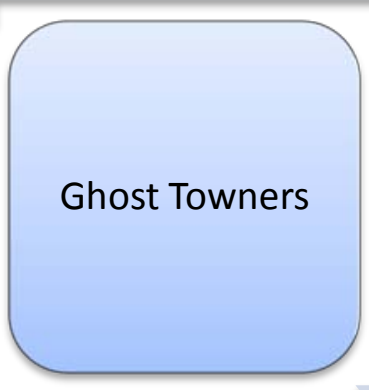

Revitalizationers and Optimistic

Bedroomers

Opportunity

\section{Pessimism}

Positive Bedroomers and the Revitalizers see an opportunity with the mill being closed.

They have an optimistic view of Weirton going forward and believe that the community will be able to survive. They believe that land sold by Weirton Steel could be developed in order to bring in tourism. Many of them also argue that Weirton's location along the Ohio River and US 22 highway access will surely bring in a new manufacturing company. A smaller number of Revitizalers believe that Weirton will capitalize on the gambling industry and will be able to spur the economy by developing new casinos. 
The Positive Bedroomers also fall into the same quadrant as the Revitalizers. They see an opportunity to become a suburb of Pittsburgh, and many believe that Weirton is already considered a suburb of Pittsburgh. They see a chance to capitalize on the community's location near Pittsburgh and some argue that a marketing campaign, along with public transportation to downtown Pittsburgh, would help Weirton's image as a suburb. Many of them also point to new development and cheaper property which will entice families to move to the community. This was a very diverse group of people, including both those who have left the community and those who have stayed. The ages of the respondents were also very diverse, as was the case for the Negative Bedroomers.

The Negative Bedroomers have a pessimistic view of Weirton's future, which is why they fall into a separate quadrant than the Positive Bedroomers. They believe that Weirton has an opportunity to become a suburb of Pittsburgh; however, they think it is their only hope. They argue that the community leaders are not doing enough to become a suburb of Pittsburgh, so they are unsure if it will happen. Some of the pessimistic Bedroomers believe that Weirton deserves better than to have its identity associated with another city and that Weirton will lose its independence.

The Ghost Towners fall into the pessimistic, no opportunity quadrant. They point to many events going on in Weirton that will make it a ghost town. They argue that Weirton has little to offer young families and that the community has become littered with little casinos and drug problems. They believe that Weirton's infrastructure will continue to decline without Weirton Steel. All of them see no opportunity for Weirton going forward and they believe that Weirton will continue to decline. The Ghost Towners were generally younger and they were made up of respondents who had already left town or planned to leave as soon as possible. 
These groups fit into the qualitative quadrants above because of their views on the community’s future and their level of optimism and pessimism. The grounded theory approach allowed the data to create common themes such as opportunity and level of optimism. Many of the respondents came right out and said if they were optimistic or pessimistic. Others did not say specifically but by using common themes and patterns found throughout the pessimistic and optimistic responses, one can group them into these categories. The pessimistic respondents believed that there was no hope but only devastation without the mill, and gambling problems that would bring the community down. The common themes in the optimistic responses were: resiliency of the community, opportunity, and the benefits of Weirton’s location, either being close to Pittsburgh, US Highway 22, or along the Ohio River.

Opportunity can also be qualitatively measured by the patterns that emerged in responses. Many respondents believe that gambling, drugs, lack of jobs, and infrastructure are key reasons why Weirton lacks opportunity. Some respondents saw opportunity without Weirton Steel. They believed that Weirton can be beautified, attract new business, develop a better gambling industry, or become a thriving suburb of Pittsburgh. These were all of the patterns that emerged in regard to individuals believing Weirton has opportunity.

\section{Weirton's Future}

Each of the three possible future narratives for Weirton, in my opinion, is realistic. The Ghost Towners who believe Weirton is well on its way to becoming desolate have the population statistics on their side. 
Table 5.2

\begin{tabular}{|c|c|c|c|c|c|c|}
\hline 1950 & 1960 & 1970 & 1980 & 1990 & 2000 & 2005 \\
\hline 24,005 & 28,201 & 27,131 & 25,371 & 22,124 & 20,411 & 19,544 \\
\hline
\end{tabular}

The trend shows that Weirton's population has been decreasing in size since the 1970's. This lends support to their theory that Weirton will become a ghost town.

The Bedroomers’ claims, that Weirton will be a suburb of Pittsburgh are also realistic. The development of Robinson Township, between Pittsburgh and Weirton, shows that this outcome is possible. Development in Weirton, such as creating new shopping centers, gives hope to the Bedroomers that Weirton can be a suburb. However, jobs in the service industry will not provide the same tax base and employee wages Weirton Steel still once did. Further evidence can be found across the river in Steubenville, Ohio, which already has advertising in Pittsburgh calling itself, “The Burb of the Burgh.”

The Revitalizers’ claims are harder to view as realistic. However, by speaking with leaders of the community who have an idea about where Weirton is heading in the future, one could possibly find support to the revitalization view. For future research, I plan to interview city leaders to see if they can back up the claims of the Revitalizers and to learn where they themselves are aligned.

I believe that Weirton will continue to have a shared narrative identity even when Weirton Steel closes for good. The community shows that they are willing to preserve their past with events marking the creation of Weirton and Weirton Steel, along with festivals in the 
summer to celebrate Weirton's heritage. The Weirton Area History Museum is another testament that Weirton is willing to keep a shared narrative identity intact.

The future shared narrative identity remains unknown, and at present there is a battle going on as to which identity will take hold: the ghost town, the bedroom community of Pittsburgh, or the new industry narrative. The claims makers for each of these narratives are different as one can see from the three groups that emerged from the data. The outcome depends on the current and former residents of the community, as they will write the next chapter in Weirton’s history.

I believe that Weirton will adopt the narrative of a bedroom community of Pittsburgh, which is the view of the majority of the Facebook respondents. However, it is going to get worse before it gets better. Weirton will continue to spend money beautifying the community and this will in turn make it a more appealing place for commuters to Pittsburgh to live. With the new developments along Colliers Way, which are reported to bring in new retailers, people who work in Pittsburgh may see a reason to live in Weirton.

The people of the community have pulled together in the past when times were tough and I believe that the same will happen in the future. Many people believed that with the demise of Weirton Steel, the community would be completely destroyed. However, the community lives on and it is due to the strong will of the citizens. I think that the community will replace Weirton Steel with a big employer but will be a sleepy community, with a rich history, for residents looking to escape the high taxes of Pennsylvania. 


\section{Limitations}

By using Facebook, I was able to reach a broad group of people from all across the United States who either called Weirton home at one time or still live there. I believe that this was the best way to gather responses beyond the local community. However, I did sacrifice having a sample that could be generalizable to the whole population of current and former residents of the community. Respondents had to have access to the internet along with a Facebook account and be members of the group, “I am from Weirton, WV.” Facebook was the most efficient way to collect such rich data within a limited time frame.

\section{Implications}

This study can be used as a framework for other researchers who are examining the effects of a major change on a community. This research lays out a roadmap for ways in which to discover narrative identities of communities and future potential narratives of communities. Performing a content analysis on historical documents, local media, and national media provides a great way for showing past narratives. The Facebook responses to the question about memories also help reinforce the past narratives. The future narratives were exposed by contacting former and current residents, through Facebook, to see what they believe lies in Weirton's future.

This thesis shows that very rich data can be obtained by contacting people through Facebook. They best way is to find a subject that you are interested in and see if there is a Facebook group to match what you are studying. Sending out a mass message to group members may turn up the most responses. However, one would have to take into account that their study may not be generalizable to their population unless they have supplemental research such as interviews. 
The study also shows that a community can have a narrative identity just as individuals can. By using grounded theory and analyzing historical documents along with the Facebook responses, I have showed that Weirton has a collective identity which is linked through narrative. Other communities may have these shared narratives as well. Future studies could be designed not only to take into account the Facebook data, but also to include interviews from the community along with more interviews of the community leaders 
ABC News. Jan. 11. 1984.

\section{Bibliography}

Alexander, Jeffrey C. 1998. Neo-Functionalism and After. New York, NY: Wiley

Banks, Ingrid. 2000. Hair Matters: Beauty, Power, and Black Women's Consciousness. New York: New York University Press.

Bell, Colin and Howard Newby. 1974. Community Studies. New York: Praeger Publishers.

Best, Joel. 2008. Social Problems. New York: W.W. Norton.

Bluestone, Barry and Bennett Harrison 1982. The Deindustrialization of America: Plant Closings, Community Abandonment, and the Dismantling of Basic Industry. New York: Basic Books

Bluestone, Barry. 1984. "Is Deindustrialization a Myth? Capital Mobility Versus Absorptive Capacity in the U.S. Economy.” Annals of the American Academy of Political and Social Science 475. Retrieved November 13, 2008. ( ://www.jstor.org/stable/1043546).

Corbin, Juliet and Anselm Strauss. 2007. Basics of Qualitative Research: Techniques and Procedures for Developing Grounded Theory. (3rd edition). Thousand Oaks, CA: SAGE.

Denzin, Norman. 1992. “Whose Cornersville is it Anyway?” Journal of Contemporary Ethnography. 21:120-132.

Foster, Elissa and Arthur P. Bochner. 2008. "Social Constructionist Perspectives in Communication Research.” Pp. 84-106 in Handbook of Constructionist Research, edited by James A. Holstein and Jaber F. Gubrium. New York: Guilford Press.

Franzosi, Roberto. 1998. "Narrative Analysis-Or Why (and how) Sociologists Should be Interested in Narrative.” Annual Review of Sociology 24. Retrieved November 182008 (http://www.jstor.org/stable/223492)

Gubrium, Jaber F. and James Holstein. 1998. "Narrative Practice and the Coherence of Person Stories.” The Sociological Quarterly 39:1. Retrieved November 182008. (http://www.jstor.org/stable/4121016).

Hamilton, Lee, Clifford L. Broman., William S. Hoffman, and Deborah S. Rener. 1990. “Hard Times and Vulnerable People: Initial Effects of Plant Closures on Autoworkers' Mental Health” Journal of Health and Social Behavior 31:2. Retrieved November 11, 2008 (://www.jstor.org/stable/2137167). 
Riessman, Catherine K. 1990 "Strategic Uses of Narrative in the Presentation of Self and Illness.” Pp. 370-375 in Social Research Methods, edited by Seal, Clive. New York: Routledge

Jones, Dennis. 2009 A. A Pageant of Nations. Weirton, WV: Weirton Area Museum and Cultural Center.

Jones, Dennis. 2009 B. Weirton Area History Game. Weirton, WV: Weirton Area Museum and Cultural Center.

Jones, Sue. 1985. “Depth Interviewing.” Pp. 257-260 in Social Research Methods, edited by Seal, Clive. New York: Routledge

Knapp, Tim and John Harms. 2002. "When the Screen Goes Blank: A Television Plant Closing and Its Impact on Workers,” The Sociological Quarterly 43:4. Retrieved November 11 2008 (http://www.jstor.org/stable/4120941).

Leahy, Peter J. and Xiannuan Lin. 1992. "Plant Closings: A Comparison to Natural Disasters,” American Journal of Economics and Sociology 51:3. Retrieved November 13, 2008 (://www.jstor.org/stable/3487316).

Levine, Arnold. 1982. “Weirton Steel.” Unpublished Manuscript.

Lieber, James B. 1995. Friendly Takeover: How an Employee Buyout Saved A Steel Town. New York: Penguin Books.

Logan, John R. and Harvey L. Molotch. 1987. Urban Fortunes: The Political Economy of Place. Berkeley, CA: University of California Press.

Lord, George F. and Albert C Price. 1992. "Growth Ideology in a Period of Decline: Deindustrialization and Reconstruction, Flint Style,” Social Problems 39:2. Retrieved November 11, 2008 (://www.jstor.org/stable/3097035).

Moser, Claus and Kalton Graham. 1971. “Questionnaires.” Pp. 73-87 in Social Research Methods, edited by Seal, Clive. New York: Routledge

Nichols, Lawrence T., and James J. Nolan III. 2004. “The Lessons of Lincoln: Regulation as Narrative in the Savings and Loan Crisis.”

Orbuch, Terri L. 1997. “People’s Accounts Count: The Sociology of Accounts.” Annual Review of Sociology 23. Retrieved November 18, 2008 (://www.jstor.org/stable/2952560).

Rader, Dobson. "Why they Fight to Save a Way of Life.” Parade, 6-9. Dec. 12. 1982 
Root, Kenneth. 1984. “The Human Response to Plant Closures,” Annals of the American Academy Of Political and Social Science 475. Retrieved November 11, 2008 (://www.jstor.org/stable/1043547).

Smucker, Ann. 1994. No Star Nights. New York, NY: Dragonfly Books.

Smith, Phillip H. 2003. Board Betrayal: The Weirton Steel Story. Pittsburgh, PA: Ladlesheet Press.

Stack, Carol B. (1975). All Our Kin: Strategies for Survival in a Black Community. New York: Harper \& Row Publishing.

Standupforsteel.com. http://www.standupforsteel.com/history.htm.

Stein, Maurice R. 1960. The Eclipse of Community: An Interpretation of American Studies. Princeton, NJ: Princeton University Press.

Turner, Bryan S. 2008. “The Constructed Body.” Pp. 493-510 in Handbook of Constructionist Research, edited by James A. Holstein and Jaber F. Gubrium. New York: Guilford Press.

United States Census Bureau 2007, County and City Data Book. $14^{\text {th }}$ Edition. Washington D.C.

United States Census Population. 1960. Volume 1. Characteristics on Population. U.S. Department of Commerce.

Weber, Robert P. 1990. “Content Analysis.” Pp. 117-124 in Social Research Methods, edited by Seal, Clive. New York: Routledge.

Weirton Steel Employees Bulletin. Dec. 1976. 43(6).

Weirton Steel Employees Bulletin. May 1976. 43(3).

Weirton Steel Employees Bulletin. Winter. 1982. 50 (1).

Weirton Steel Employees Bulletins. 1965-1985

Whyte, William. 1942. Street Corner Society: The Social Structure of an Italian Slum. Chicago: the University of Chicago Press.

--------. 1993. Revisiting "Street Corner Society," Sociological Forum, 8, Retrieved July 29, 2009, from http://jstor.org/stable/684639.

-------. 1994. Participant Observer: An Autobiography. Ithica, NY: Cornell University.

Wu, Sen-Yuan and Hyman Korman. 1987. "Socioeconomic Impacts of Disinvestments on Communities in the New York State,” American Journal of Economics and Sociology 46:3. Retrieved November 132008 (://www.jstor.org/stable/3486077). 


\section{Appendix:}

\section{Questionnaire Sent to Facebook Members:}

Hi, my name is Jason Rine. I was born and raised in Weirton (Weir High graduate, 2004). I am now a graduate student in Sociology at WVU in Morgantown. Like many of you I am concerned about the future of our community. For this reason I am conducting my Master's Thesis research about Weirton and how it has changed over time. I was hoping that some of you would be willing to share your thoughts, feelings, and memories of Weirton. I know your time is valuable and no one likes to fill out long surveys. If you can spare a few minutes to answer at least the first question, it would be very helpful to me.

Q1. What will be the next chapter in Weirton's story? For instance, do you believe that Weirton will develop a new industry, become a ghost town, or become a bedroom community of Pittsburgh? Do you have a more optimistic or pessimistic view of Weirton's future?

If you have some more time and would like to help me further, please consider answering the following questions:

Q2. When did you first arrive in Weirton? What brought you to our city, and when did you leave (if you have left)? If you have moved away, why?

Q3. Were you or a member of your family ever employed at Weirton Steel?

Q4. What about Weirton is most memorable to you and why?

Q5. It would be helpful if you could include your sex and age as well.

Q6. I would also be interested in any comments regarding: Political leadership, community leadership, how Weirton was treated by national leaders, or anything else you think would be helpful to my study.

I am eager to hear your thoughts about these questions. If you are willing to share your memories, please send me an email at: weirton-memories@mail.wvu.edu or send a letter to:

Weirton Memories,

Box 6326

West Virginia University

Morgantown, WV 26506-6326 
Your response will be treated with confidence. I will not divulge any personally identifiable information about you in my thesis or the articles I write from this research. No one is obligated to write to me and obviously no harm will come from ignoring this request. Still, it is your stories that will make this project a success.

I will report back to the group when the project is complete with a link to the thesis. I will also summarize and post the results of the study to our group. Feel free to contact me via Facebook or jrine3@mix.wvu.edu.

\section{Pictures from Facebook:}

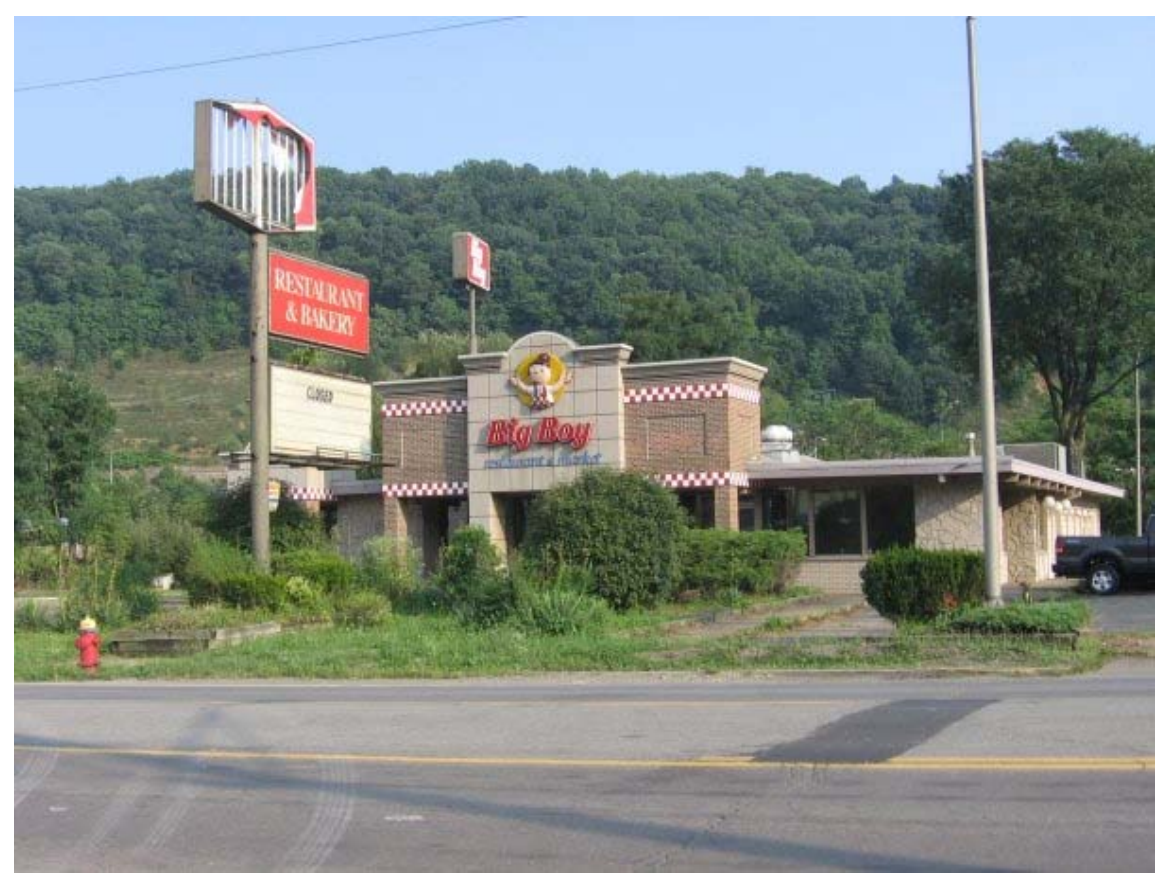



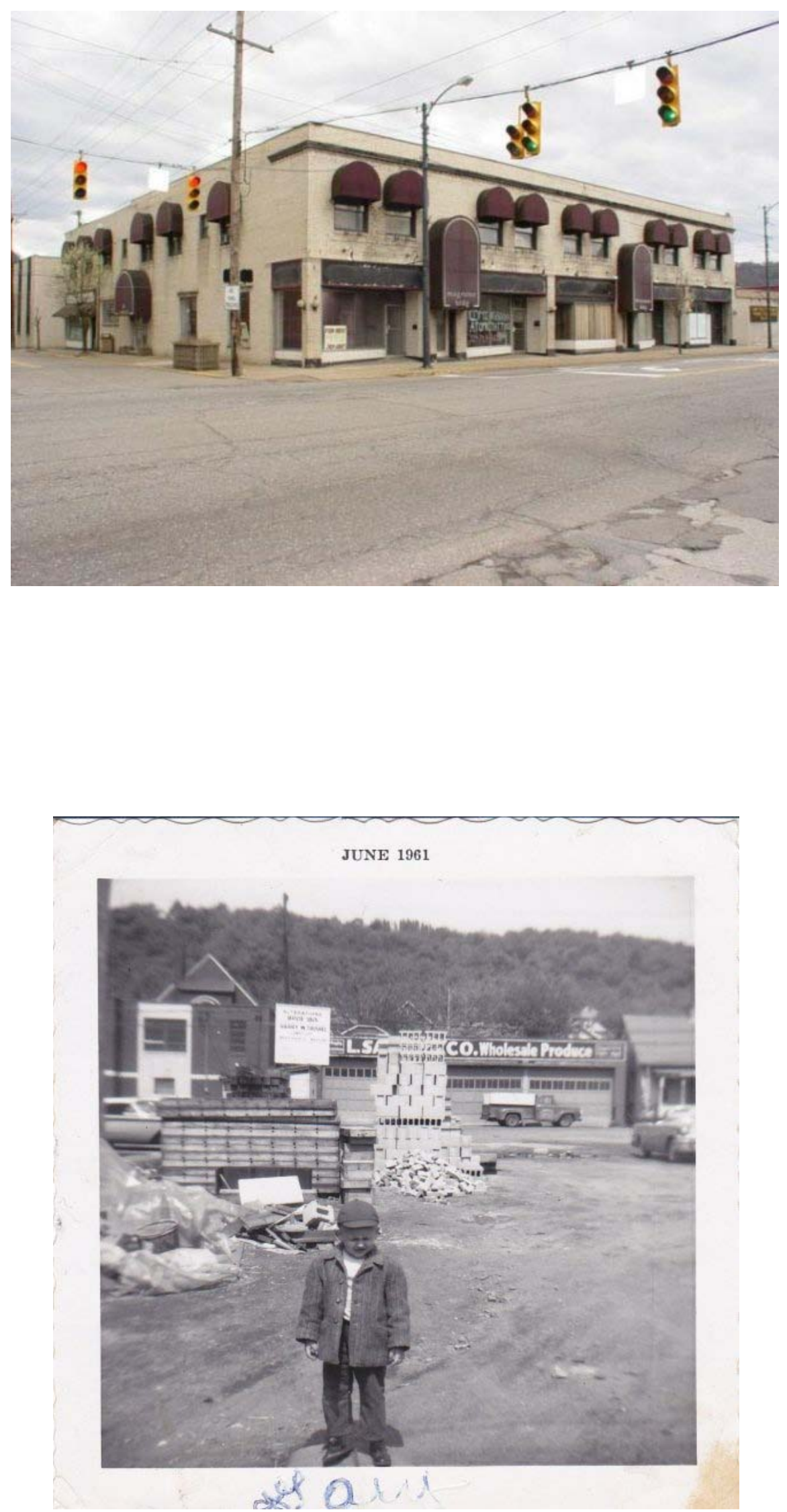


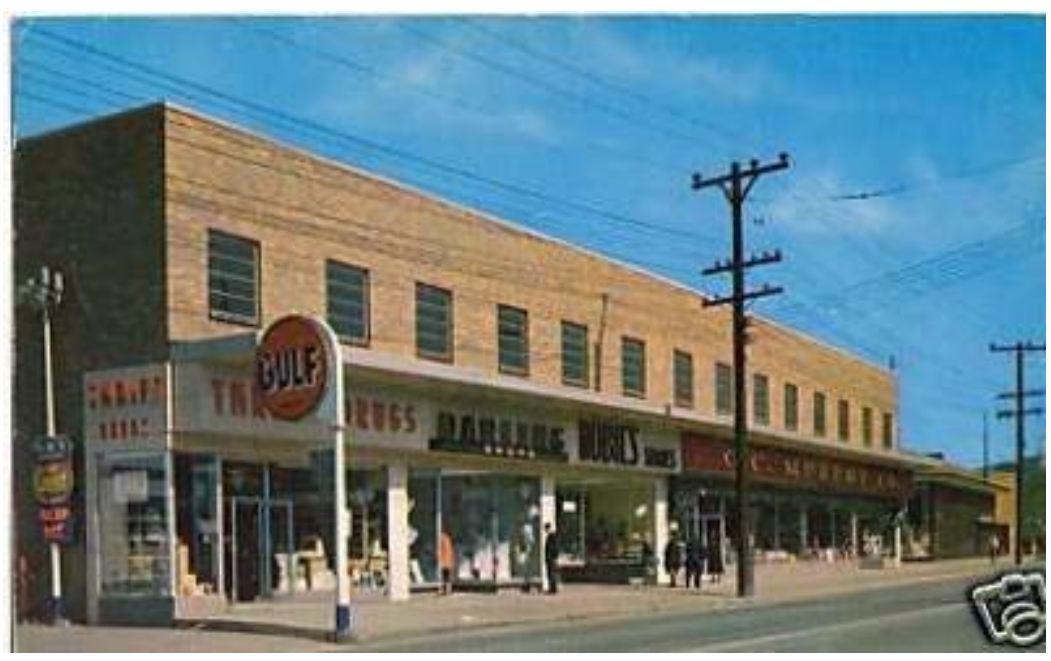

Weirton Steel Bulletins:

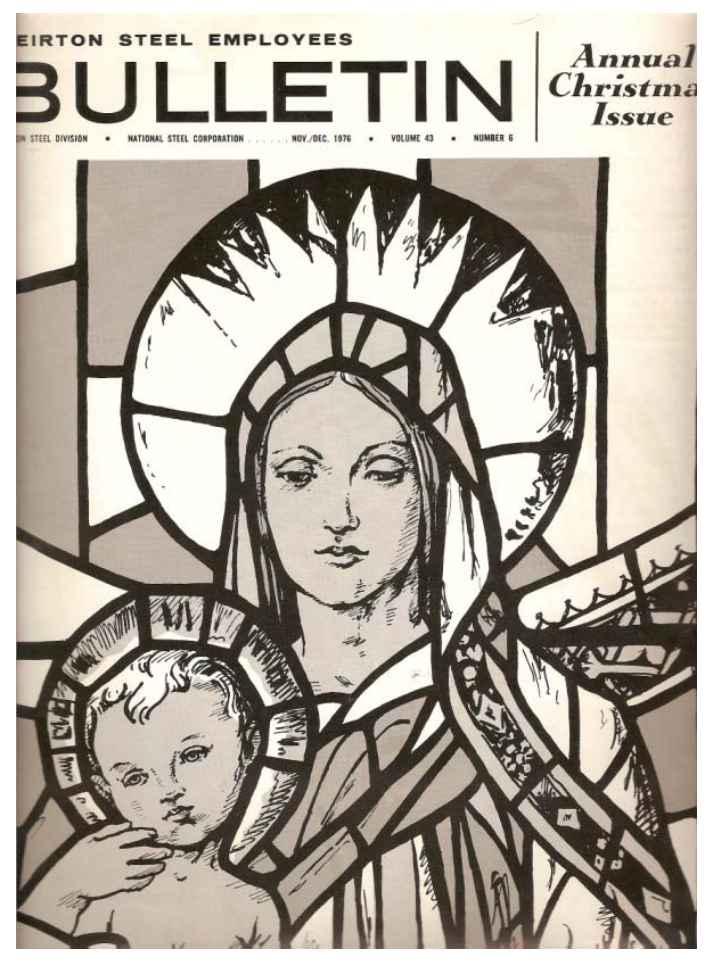



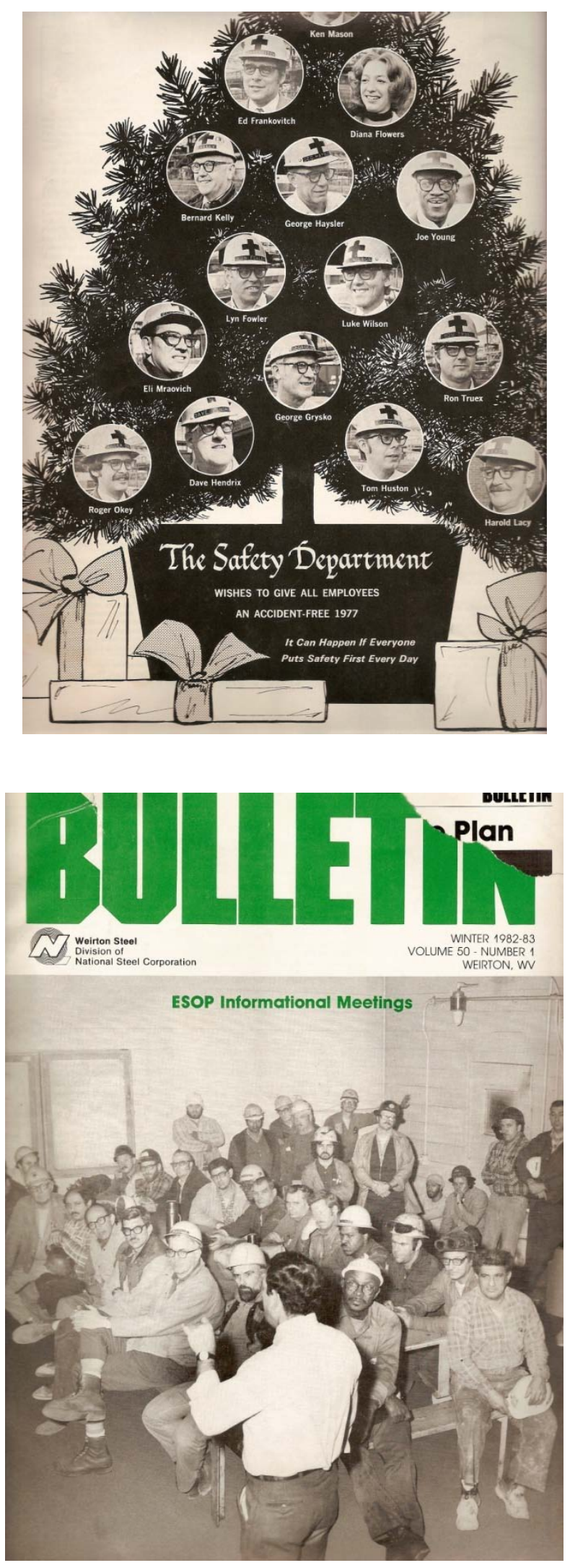


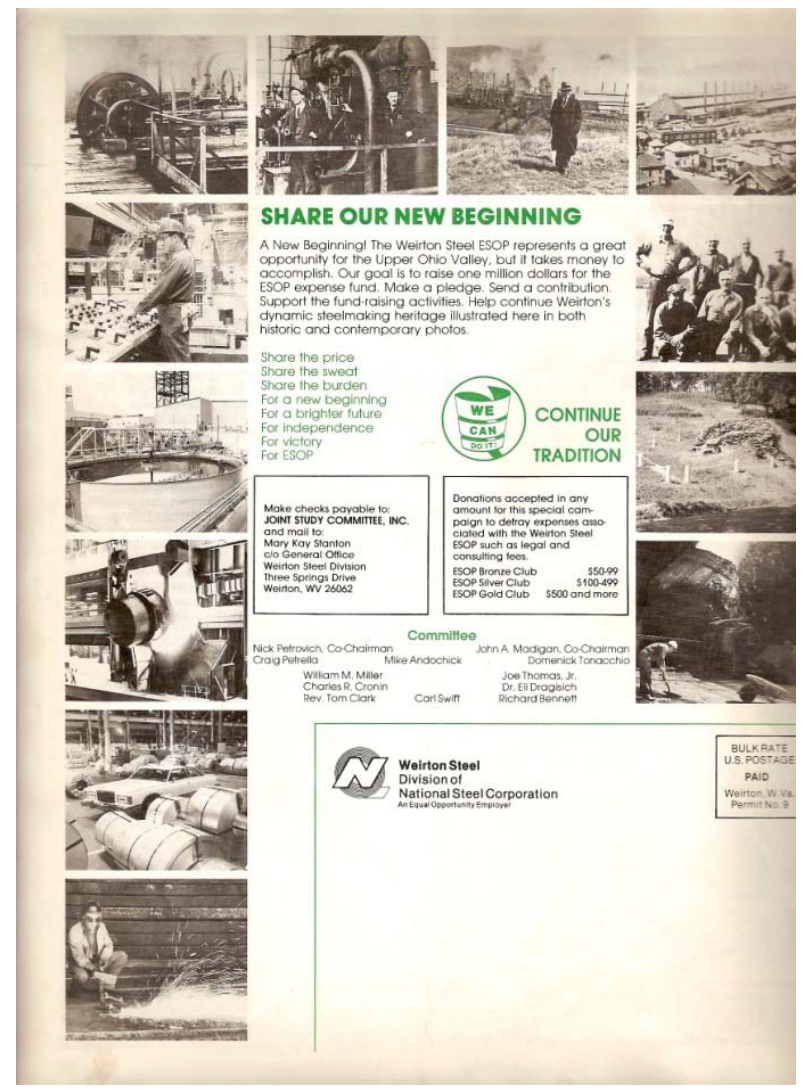

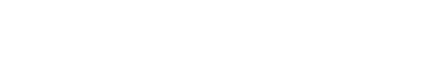

